\title{
Connexin Hemichannel Mimetic Peptide Attenuates Cortical Interneuron Loss and Perineuronal Net Disruption Following Cerebral Ischemia in Near-Term Fetal Sheep
}

\author{
Panzao Yang ${ }^{1}$, Joanne O. Davidson ${ }^{1}$, Tania M. Fowke ${ }^{1}$, Robert Galinsky ${ }^{2}$, Guido Wassink ${ }^{1}$, \\ Rashika N. Karunasinghe ${ }^{1}$, Jaya D. Prasad ${ }^{1}$, Sumudu Ranasinghe ${ }^{1}$, Colin R. Green ${ }^{3}{ }^{\circ}$, \\ Laura Bennet $^{1}$, Alistair J. Gunn ${ }^{1}$ (D) and Justin M. Dean ${ }^{1, * \mathbb{D}}$ \\ 1 Department of Physiology, Faculty of Medical and Health Sciences, University of Auckland, Auckland 1145, \\ New Zealand; p.yang@auckland.ac.nz (P.Y.); joanne.davidson@auckland.ac.nz (J.O.D.); \\ t.fowke@mimetas.com (T.M.F.); g.wassink@auckland.ac.nz (G.W.); \\ rashika.karunasinghe@auckland.ac.nz (R.N.K.); j.prasad@auckland.ac.nz (J.D.P.); \\ s.ranasinghe@auckland.ac.nz (S.R.); 1.bennet@auckland.ac.nz (L.B.); aj.gunn@auckland.ac.nz (A.J.G.) \\ 2 The Ritchie Centre, Hudson Institute of Medical Research, Melbourne, Victoria 3168, Australia; \\ robert.galinsky@hudson.org.au \\ 3 Department of Ophthalmology, Faculty of Medical and Health Sciences, University of Auckland, \\ Auckland 1145, New Zealand; c.green@auckland.ac.nz \\ * Correspondence: j.dean@auckland.ac.nz; Tel.: +64-9-373-7599 (ext. 86201)
}

Received: 12 August 2020; Accepted: 2 September 2020; Published: 4 September 2020

\begin{abstract}
Perinatal hypoxia-ischemia is associated with disruption of cortical gamma-aminobutyric acid (GABA)ergic interneurons and their surrounding perineuronal nets, which may contribute to persisting neurological deficits. Blockade of connexin 43 hemichannels using a mimetic peptide can alleviate seizures and injury after hypoxia-ischemia. In this study, we tested the hypothesis that connexin 43 hemichannel blockade improves the integrity of cortical interneurons and perineuronal nets. Term-equivalent fetal sheep received $30 \mathrm{~min}$ of bilateral carotid artery occlusion, recovery for $90 \mathrm{~min}$, followed by a $25-\mathrm{h}$ intracerebroventricular infusion of vehicle or a mimetic peptide that blocks connexin hemichannels or by a sham ischemia + vehicle infusion. Brain tissues were stained for interneuronal markers or perineuronal nets. Cerebral ischemia was associated with loss of cortical interneurons and perineuronal nets. The mimetic peptide infusion reduced loss of glutamic acid decarboxylase-, calretinin-, and parvalbumin-expressing interneurons and perineuronal nets. The interneuron and perineuronal net densities were negatively correlated with total seizure burden after ischemia. These data suggest that the opening of connexin 43 hemichannels after perinatal hypoxia-ischemia causes loss of cortical interneurons and perineuronal nets and that this exacerbates seizures. Connexin 43 hemichannel blockade may be an effective strategy to attenuate seizures and may improve long-term neurological outcomes after perinatal hypoxia-ischemia.
\end{abstract}

Keywords: interneuron; perineuronal net; hypoxia-ischemia; fetus; connexin hemichannel

\section{Introduction}

Perinatal hypoxic-ischemic encephalopathy remains a major cause of brain damage in term and near-term infants worldwide [1]. Gamma-aminobutyric acid (GABA)ergic interneurons are the main inhibitory neurons in the brain and integration of GABAergic interneurons into the cerebral cortex in late gestation plays an important role in normal cortical development and function [2,3]. Glutamate decarboxylase (GAD) is an enzyme that catalyzes decarboxylation of glutamate to form 
GABA and is expressed in all GABAergic interneurons, while parvalbumin ${ }^{+}$, calretinin ${ }^{+}$, and calbindin ${ }^{+}$ interneurons form the major GABAergic interneuron subtypes. Experimental and human studies show that cortical interneurons are critical for normal cognitive processes, including executive function, learning, memory, and intelligence [2,4-6]. Limited human studies have also shown altered interneuron function after neonatal brain injury, including reduced cortical interneuron migration, loss of cortical GABAergic interneurons, and reduced GABAergic signaling [4,7]. Further, interneuron dysfunction and unbalanced excitatory-inhibitory activity in the cortex have been shown in developmental neurological disorders, including cognitive disabilities, epilepsy, and autism $[5,6,8]$. Thus, disruption of cortical inhibitory interneuron circuits may contribute to disability after moderate to severe hypoxic-ischemic encephalopathy in term infants.

Perineuronal nets (PNNs) are mesh-like structures of the extracellular matrix (ECM) that envelop the cell bodies and proximal neurites of subpopulations of neurons, including interneurons in the cerebral cortex [9]. PNNs are composed of a backbone of hyaluronic acid polymer joined to chondroitin sulfate proteoglycans via link proteins and tenascins $[10,11]$. PNNs help control normal GABAergic interneuron physiology, including regulating the formation and stabilization of synapses, ref [12] providing physical protection to neurons, mediating signal transduction, and controlling neuronal activity [13]. Disruption of PNNs has also been reported in a range of neurological diseases such as schizophrenia, ref [14] Alzheimer's disease, ref [15] and epilepsy [16]. Further, we recently reported loss of PNNs on cortical interneurons after hypoxia-ischemia (HI) in term-equivalent fetal sheep [17]. Thus, changes in cortical interneuron PNN expression may be an important component of interneuron dysfunction and neurological disability following neonatal brain injury. However, there is limited evidence for therapeutic strategies to prevent interneuron injury, including PNN disruption, in the developing brain.

Gap junctions are intercellular channels that allow the movement of small molecules and ions between cells. Functional gap junctions are formed by docking of two hemichannels between adjacent cells. Undocked hemichannels are in a closed state under normal physiological conditions [18]. Connexin43 is the predominant connexin hemichannel in the brain and is mainly expressed on astrocytes [19]. In humans, the expression of connexin 43 is markedly upregulated after cerebral ischemia [20]. In near-term fetal sheep, we reported abnormal opening of connexin 43 hemichannels in the brain after HI, while blockade of connexin 43 hemichannel signaling using a mimetic peptide (peptide 5) reduced brain injury and improved neuronal function [21,22]. However, the impact of connexin43 hemichannel opening on cortical interneuron cell death and function, including loss of PNNs, after neonatal HI is unknown. Thus, in the present study, we tested the hypothesis that blockade of connexin 43 hemichannel opening during early recovery from $\mathrm{HI}$ in fetal sheep at 0.85 of gestation, when the brain maturation is broadly similar to the term human infant, $[23,24]$ would improve cortical GABAergic interneuron survival, prevent loss of PNNs, and improve neurophysiological function.

\section{Results}

\subsection{Survival of GABAergic Interneurons in the Parasagittal Cortex after Cerebral Ischemia}

Representative photomicrographs of $\mathrm{GAD}^{+}$, parvalbumin ${ }^{+}$, calretinin ${ }^{+}$, and calbindin- $28 \mathrm{k}^{+}$ neurons in all treatment groups are shown in Figure 1 (arrowheads). Note that ischemia + vehicle animals showed aggregates of dark parvalbumin and calretinin staining in the cytoplasm of some cortical neurons (arrows), which were not observed in sham control and ischemia + peptide animals. 

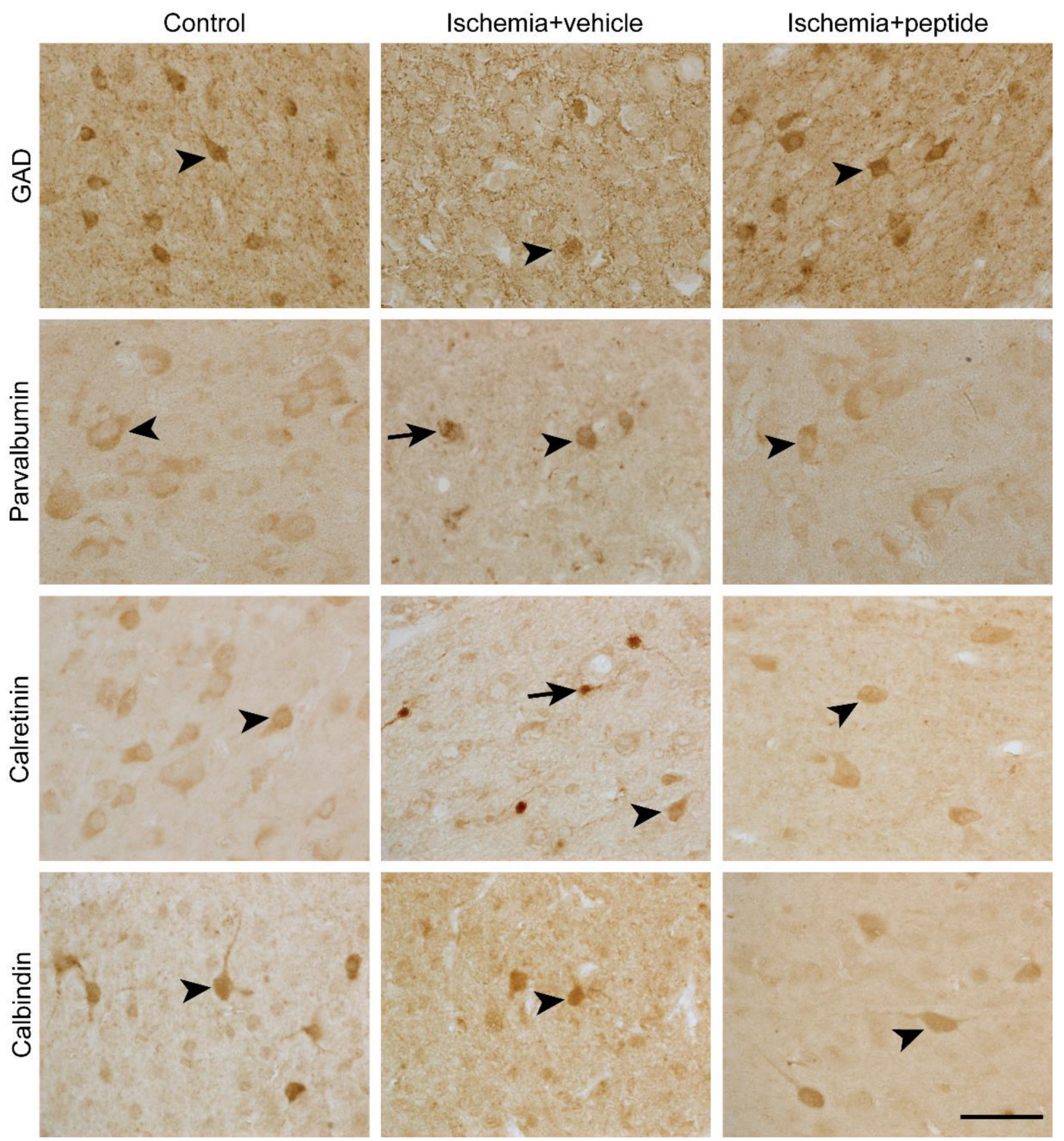

Figure 1. Photomicrographs of glutamate decarboxylase $(\mathrm{GAD})^{+}$, parvalbumin $^{+}$, calretinin $^{+}$, and calbindin ${ }^{+}$cortical interneurons in sham control, cerebral ischemia (ischemia + vehicle), and cerebral ischemia + mimetic peptide treatment (ischemia + peptide) groups at 7 days recovery. Black arrowheads show examples of neurons that were included in cell counting. Black arrows show examples of neurons with cytoplasmic aggregates, which were excluded from cell counting. Scale bar: $50 \mu \mathrm{m}$.

Cerebral ischemia and peptide 5 treatment were associated with significant overall changes in interneuron density in the parasagittal cortex (Figure 2, one-way ANOVA; GAD ${ }^{+}, p=0.013$; parvalbumin $^{+}, p=0.03$; calretinin ${ }^{+}, p=0.001$; and calbindin ${ }^{+}, p=0.04$ ). Post hoc analysis (Fisher's Fisher's least significant difference (LSD test)) showed a significant reduction in the density of GAD ${ }^{+}$ cells $\left(p=0.006\right.$; Figure 2A), parvalbumin ${ }^{+}$cells $(p=0.03$; Figure $2 \mathrm{~B})$, calretinin ${ }^{+}$cells $(p=0.007$; Figure 2C), and calbindin-28k ${ }^{+}$cells $(p=0.04$; Figure 2D) in the parasagittal cortex of ischemia + vehicle animals compared with sham controls. By contrast, in the ischemia + peptide group there was a significantly higher density of $\mathrm{GAD}^{+}$cells $(p=0.036$; Figure $2 \mathrm{~A})$, parvalbumin ${ }^{+}$cells $(p=0.017$; Figure 2B), and calretinin ${ }^{+}$cells $(p=0.041$; Figure $2 \mathrm{C})$ but not of calbindin- $28 \mathrm{k}^{+}$cells $(p>0.999$; Figure 2D), in the parasagittal cortex compared with ischemia + vehicle animals, indicating significantly greater survival of those cell types after peptide 5 treatment. 

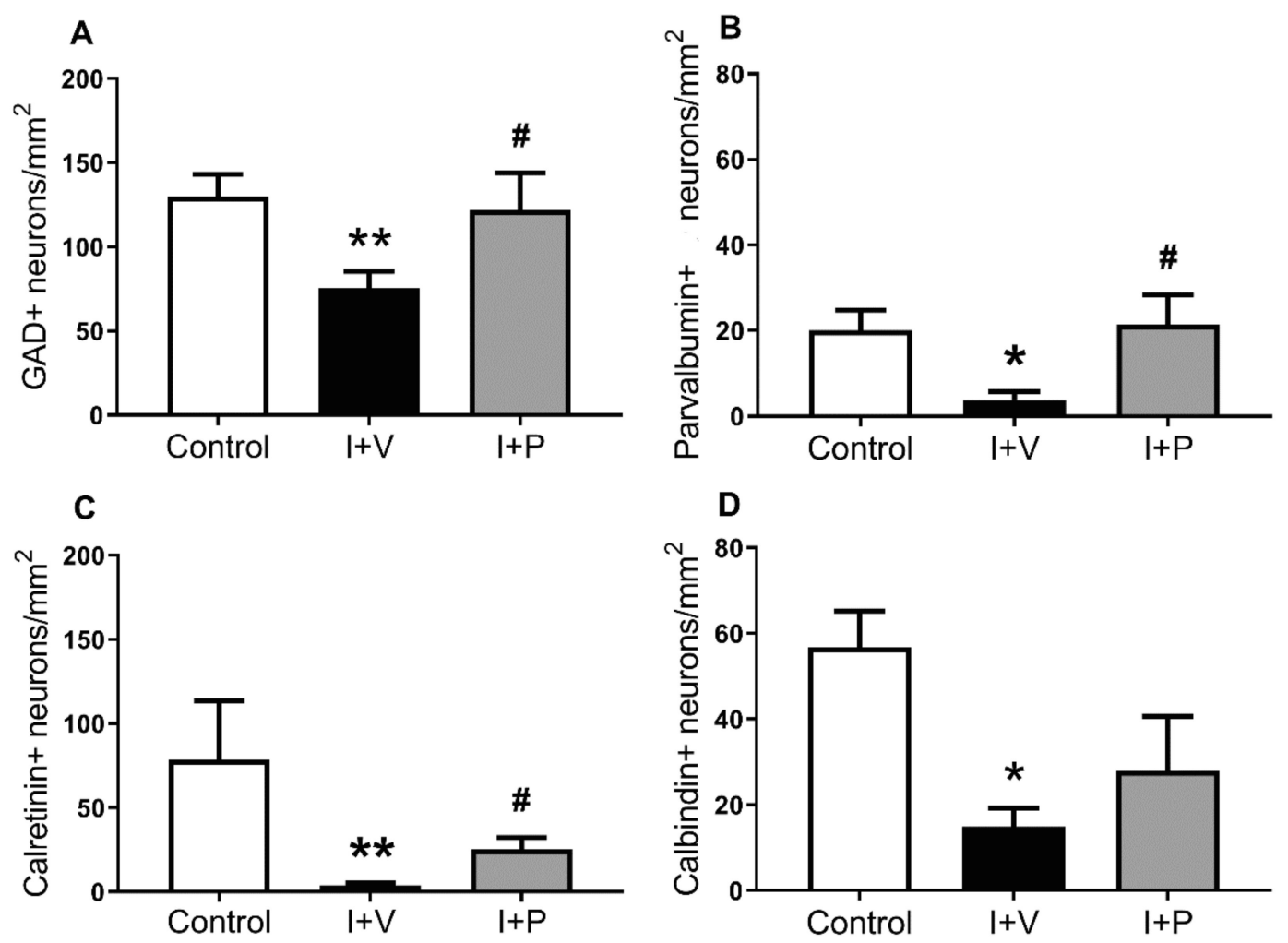

Figure 2. Interneuron survival in all layers of the parasagittal cortex in sham control (control), cerebral ischemia (ischemia + vehicle $(\mathrm{I}+\mathrm{V})$ ), and cerebral ischemia + mimetic peptide treatment (ischemia + peptide $(\mathrm{I}+\mathrm{P})$ ) groups at 7 days recovery. Densities $\left(\right.$ cells $\left./ \mathrm{mm}^{2}\right)$ of $(\mathrm{A})$ glutamate decarboxylase $(\mathrm{GAD})^{+},(\mathbf{B})$ parvalbumin $^{+},(\mathbf{C})$ calretinin $^{+}$, and (D) calbindin ${ }^{+}$interneurons. Data are mean \pm standard error of the mean. Sham control group (GAD, $n=8$ animals; parvalbumin, $n=4$; calretinin, $n=6$; and calbindin, $n=5)$. I $+\mathrm{V}$ group (GAD, $n=10$; parvalbumin, $n=6$; calretinin, $n=6$; and calbindin, $n=4)$. I + P group (GAD, $n=5$; parvalbumin, $n=5$; calretinin, $n=5$; and calbindin, $n=5) .{ }^{*} p<0.05$ and ${ }^{* *} p<0.01$ ischemia vs. control; ${ }^{*} p<0.05$ treatment vs. ischemia. Note that analysis of cell densities was performed on single antibody-labelled brain sections (two sections per marker per animal) visualized with 3,3'-diaminobenzidine tetrahydrochloride hydrate staining. Cells were counted in all layers of the first and second gyri of the parasagittal cortex (see Figure 6) using transmitted light microscopy (40× objective) and the fractionator probe (see Section 4. Materials and Methods, Image Analysis subsection). Positive cells were selected based on a typical pattern of cytoplasm staining and cellular morphology (c.f. control neurons in Figure 1).

\subsection{Changes in PNNs in Layer 6 of the Parasagittal Cortex Following Cerebral Ischemia}

Next, we assessed changes in PNN expression in layer 6 of the parasagittal cortex in the sham control, ischemia + vehicle, and ischemia + peptide groups. In uninjured control animals, Wisteria floribunda agglutinin (WFA) staining showed a pattern of dense pericellular labelling (i.e., PNNs; Figure 3A,D,G (arrows)), including on GAD ${ }^{+}$cells (Figure 3G), and a more diffuse extracellular labelling (e.g., Figure 3D (layer 6 region defined within dotted lines)). Animals in the ischemia + vehicle group showed a marked reduction in WFA staining in layer 6 throughout the parasagittal cortex (Figure 3B) compared with controls (Figure 3A), which involved loss of both the PNN and diffuse ECM components (e.g., Figure 3E,H). By contrast, ischemia + peptide animals showed normal WFA labelling in both the PNN and diffuse ECM components (Figure 3C,F,I). 

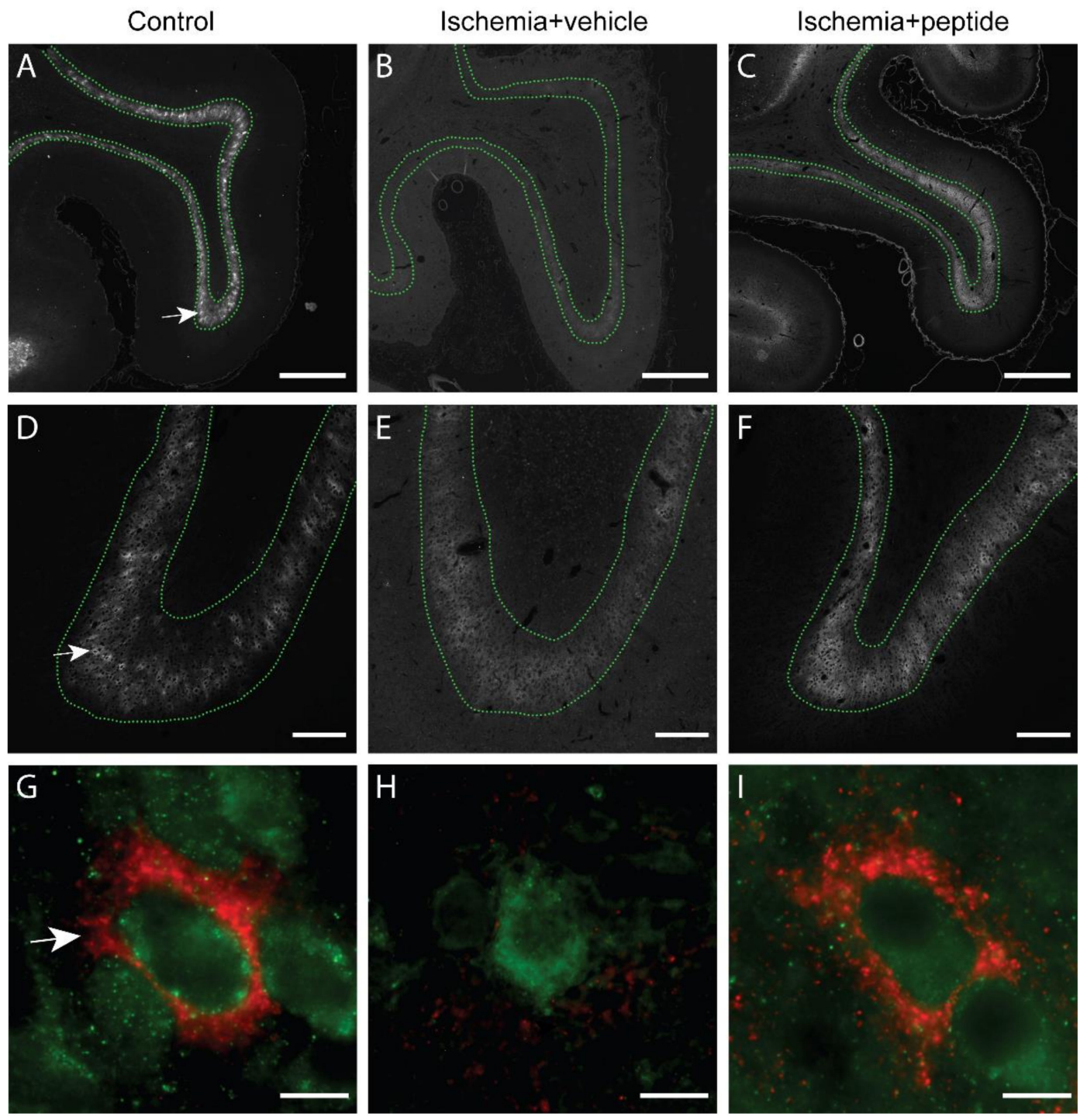

Figure 3. Immunofluorescent labelling of Wisteria floribunda agglutinin (WFA) ${ }^{+}$perineuronal nets (PNNs) and glutamate decarboxylase (GAD) ${ }^{+}$interneurons in the parasagittal cortex in the sham control (A,D,G), cerebral ischemia (ischemia + vehicle; $\mathbf{B}, \mathbf{E}, \mathbf{H})$, and cerebral ischemia + mimetic peptide treatment (ischemia + peptide; $\mathbf{C}, \mathbf{F}, \mathbf{I})$ groups at 7 days recovery. Note: images (B and $\mathbf{E}$ ) (ischemia + vehicle group) were obtained at $5 \times$ higher exposure times than other images (sham control and ischemia + peptide groups) to allow visualization of WFA staining. (A-F) show WFA staining where the layer 6 region is defined within dotted lines. (G-I) show WFA ${ }^{+}$PNNs (red) with $\mathrm{GAD}^{+}$interneuron (green) staining. PNNs are indicated by white arrows (A,D,G). Scale bars: $1 \mathrm{~mm}(\mathbf{A}-\mathbf{C}) ; 200 \mu \mathrm{m}(\mathbf{D}-\mathbf{F})$; $10 \mu \mathrm{m}(\mathbf{G}-\mathbf{I})$.

We then quantified the effect of $\mathrm{HI}$ on the number of PNNs in layer 6 of the parasagittal cortex (Figure 4). There was a significant overall effect of treatment on the densities of WFA ${ }^{+}$neurons (one-way ANOVA; $p=0.0041$ ), GAD ${ }^{+}$neurons (one-way ANOVA; $p<0.0002$ ), and the percentage of $\mathrm{GAD}^{+}$ neurons expressing WFA (one-way ANOVA; $p=0.0085$ ). Post hoc analysis (Fisher's LSD test) showed a significant reduction in the density of $\mathrm{WFA}^{+}$cells $(p=0.0069$; Figure $6 \mathrm{~A}), \mathrm{GAD}^{+}$cells $(p<0.0001$; Figure $4 \mathrm{~B})$, and the percentage of $\mathrm{GAD}^{+}$neurons expressing WFA $(p=0.0305$; Figure $4 \mathrm{C})$ in the parasagittal cortex of ischemia + vehicle animals compared with sham controls. By contrast, ischemia + peptide was associated with a significantly greater density of $\mathrm{WFA}^{+}$cells $(p=0.003$; Figure $4 \mathrm{~A}), \mathrm{GAD}^{+}$ cells $(p=0.03$; Figure $4 \mathrm{~B})$, and the percentage of $\mathrm{GAD}^{+}$neurons expressing WFA $(p=0.004$; Figure $4 \mathrm{C})$ in layer 6 of the parasagittal cortex compared with the ischemia + vehicle group. 

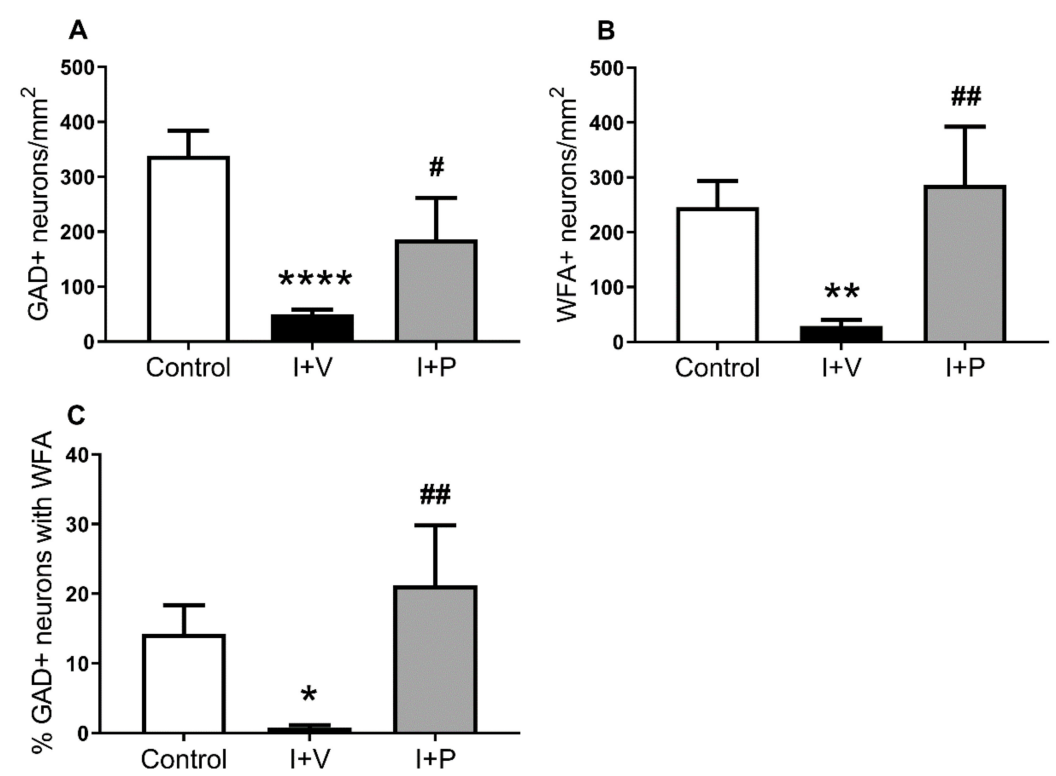

Figure 4. Interneuron survival and changes in perineuronal nets (PNNs) in layer 6 of the parasagittal cortex in sham control (control), cerebral ischemia (ischemia + vehicle $(\mathrm{I}+\mathrm{V})$ ), and cerebral ischemia + memetic peptide treatment (ischemia + peptide $(\mathrm{I}+\mathrm{P})$ ) groups at 7 days recovery. Densities (cells $/ \mathrm{mm}^{2}$ ) of interneurons and PNNs identified with glutamate decarboxylase (GAD) ${ }^{+}$ (A), Wisteria floribunda agglutinin (WFA) (B), and the percentage of GAD ${ }^{+}$interneurons with PNNs (C). Data are mean \pm standard error of the mean. Control group ( $n=6$ animals). I + V group $(n=9)$. $\mathrm{I}+\mathrm{P}$ group $(n=5) .{ }^{*} p<0.05,{ }^{* *} p<0.01$, and ${ }^{* * * *} p<0.0001$ ischemia vs. control; ${ }^{*} p<0.05$ and \#\# $p<0.01$ treatment vs. ischemia. Note that analysis of cell densities was performed on double-labelled brain sections visualized with immunofluorescence detection. GAD ${ }^{+}$cells and PNNs (c.f. controls in Figure 3) were counted in layer 6 of the first and second gyri of the parasagittal cortex (see Figure 5) using reflected fluorescence microscopy (40× objective) and the fractionator probe (see Section 4 . Materials and Methods, Image Analysis subsection).

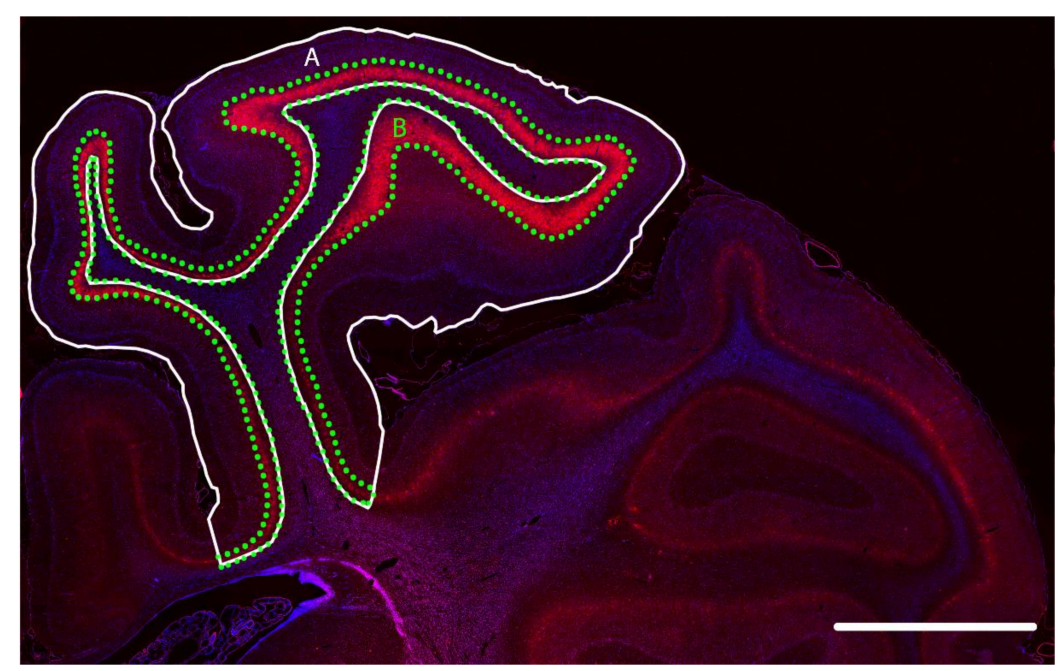

Figure 5. Sampling regions in the right parasagittal cortex of the near-term fetal sheep brain: Representative regions of interest for tracing (A) all layers of the cortices of the first two parasagittal gyri at the level of the mid-striatum (solid line) and (B) the dense Wisteria floribunda agglutinin (WFA; red staining) ${ }^{+}$layer (layer 6; dotted line). Blue staining, nuclear labelling with Hoechst. Scale bar: $5 \mathrm{~mm}$. 


\subsection{Correlations with Seizure Burden}

Finally, we examined the relationship between the density of $\mathrm{GAD}^{+}$neurons or PNNs in cortical layer 6 with seizure burden (cumulative total min of all seizures) in all animals. There were negative relationships between seizure burden and the densities of $\mathrm{GAD}^{+}$neurons (Figure 6A; $r^{2}=0.39$ ), parvalbumin ${ }^{+}$neurons (Figure $6 \mathrm{~B} ; r^{2}=0.34$ ), calretinin ${ }^{+}$neurons (Figure $6 \mathrm{C} ; r^{2}=0.53$ ), PNNs (Figure 6E; $r^{2}=0.98$ ), and the percentage of $\mathrm{GAD}^{+}$neurons with PNNs (Figure $6 \mathrm{~F} ; r^{2}=0.92$ ). Note that this relationship was strongest for PNNs and \%GAD/PNNs. No relationship was found between seizure burden and the density of calbindin ${ }^{+}$neurons (Figure 6D).

A

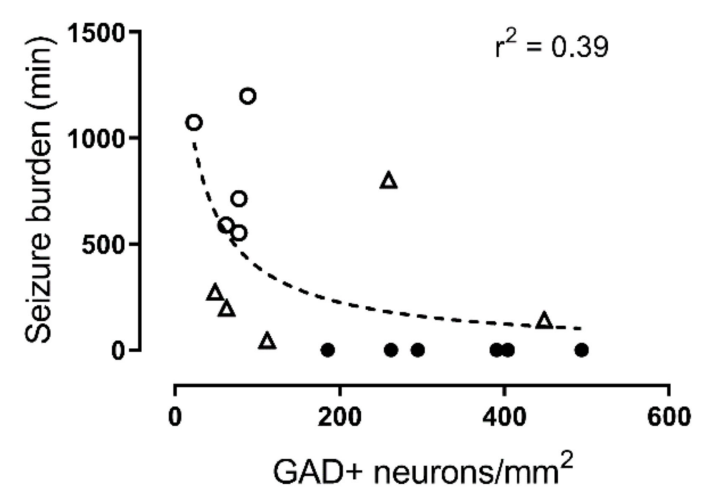

C

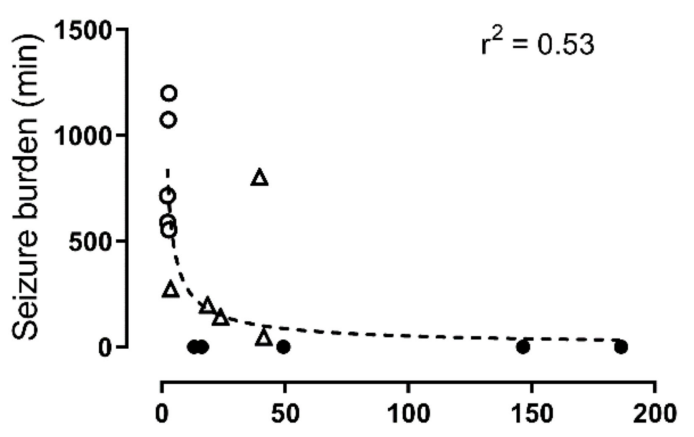

Calretinin + neurons $/ \mathrm{mm}^{2}$

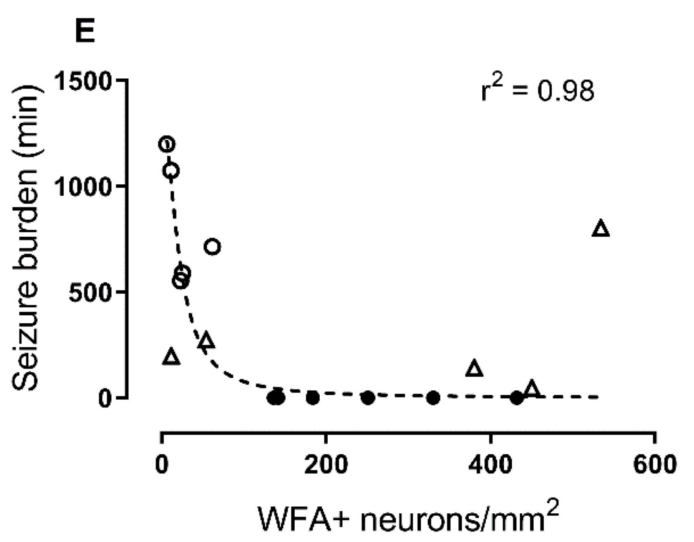

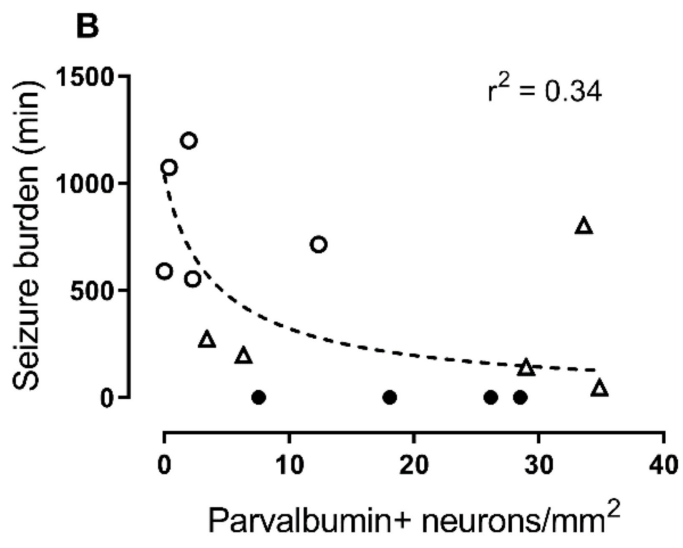

D

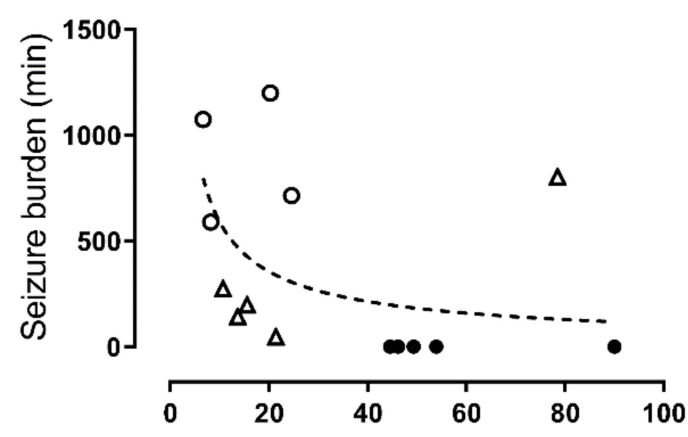

Calbindin+ neurons $/ \mathrm{mm}^{2}$

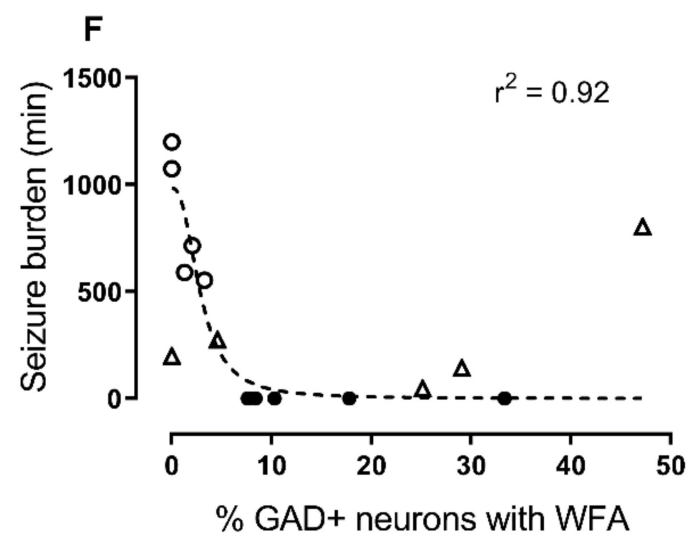

Figure 6. Nonlinear regression (sigmoidal curve fit) of the relationship of interneurons and perineuronal nets (PNNs) with total seizure burden (min): (A) Glutamate decarboxylase (GAD) ${ }^{+},\left(\right.$B) parvalbumin ${ }^{+}$, (C) calretinin $^{+}$, (D) calbindin ${ }^{+}$interneuron density, (E) Wisteria floribunda agglutinin (WFA) ${ }^{+}$neuronal density (i.e., PNNs), and (F) the percentage of $\mathrm{GAD}^{+}$neurons with PNNs $\left(\mathrm{WFA}^{+}\right)$. Sham control group ( $n=6$ animals; closed circles). Ischemia + vehicle group $(n=5 ;$ open circles). Ischemia + peptide group ( $n=5$; open triangles). 


\section{Discussion}

There is increasing evidence that injury to cortical interneurons, including loss of PNNs and disruption of inhibitory interneuron circuits, is an important contributor to neurological disability following neonatal brain injury $[17,25,26]$. The present study demonstrates that blockade of connexin 43 hemichannel opening with a mimetic peptide during early recovery from $\mathrm{HI}$ in term-equivalent fetal sheep improved survival of cortical GABAergic interneurons and prevented loss of cortical PNNs after 7 days of recovery. Further, this protection was associated with reduced total seizure burden measured from the cortical electroencephalogram (EEG). Overall, these data suggest that connexin 43 hemichannel opening contributes to interneuron cell death and deficits in interneuron PNNs following $\mathrm{HI}$, resulting in altered cortical inhibitory network function. Since peptide 5 at the levels used here does not uncouple gap junctions, [27] these data suggest that blockade of connexin hemichannels rather than gap junction communication between cells may be an effective treatment strategy for improving neurological outcomes following neonatal brain injury.

Damage to the parasagittal cortex in term infants after $\mathrm{HI}$ is highly associated with poor neurodevelopmental outcomes including cognitive and learning deficits and epilepsy [28-31]. In the present study, cerebral ischemia in near-term fetal sheep was associated with a pattern of parasagittal cortical damage after 7 days of recovery, which included a marked reduction in the survival of cortical $\mathrm{GAD}^{+}$, parvalbumin ${ }^{+}$, calretinin ${ }^{+}$, and calbindin ${ }^{+}$interneuron populations. These findings are broadly consistent with previous studies showing loss and disrupted development of interneurons in the cerebral cortex and subcortical grey matter following $\mathrm{HI}$ in preterm and term fetal sheep $[17,32-35]$ and neonatal rodents [36-43] and following ventilatory support in preterm baboons [44]. Although there are no comparable term human data, limited pathology and imaging studies in preterm infants have shown reductions in the numbers and complexity of cortical interneurons, refs [25,45] cortical interneuron migration, [7] interneuron neurogenesis, [46] and cortical GABAergic signaling [4]. Disruptions in interneuron function, resulting in reduced inhibitory control [47] and loss of the neurotrophic function of GABA, [48] are also implicated in many neurodevelopmental disorders including lissencephaly, intellectual disabilities, anxiety disorders, autism spectrum disorders, schizophrenia, and early life epilepsies [6,8,47,49-53]. Similarly, experimental disturbances in interneuron survival and function during brain development in animals are associated with a range of learning and behavioral deficits [54,55]. Thus, given the key roles of GABAergic neurons in normal cortical development and function, refs $[3,56-58]$ loss of cortical neurons and associated disruptions in cortical interneuron circuitry may be important contributors to the long-lasting adverse neurophysiological outcomes associated with $\mathrm{HI}$ in term infants.

PNNs are also important contributors to inhibitory circuits [12,59-61]. In the present study, cerebral ischemia was associated with marked loss of the total number of PNNs and the percentage of PNNs on surviving $\mathrm{GAD}^{+}$interneurons in layer 6 of the parasagittal cortex (the majority of PNNs are located within this layer in near-term fetal sheep [17]). Thus, although some of this PNN loss is related to interneuron death, these findings suggest that HI can directly affect the development and/or integrity of PNNs independent of interneuron survival. In support, disruptions in various components of PNNs were previously reported in the cortex and other subcortical structures following HI [62-65] or infection [25] in newborn rodents and after stroke or seizures in adult rats and sheep [16,66-70]. We also observed a strong relationship between loss of PNNs and seizure burden following HI, supporting a causative role of cortical interneuron dysfunction in the development of cortical hyperexcitability and seizures. Consistent with this, increased neuronal excitability and seizures were shown following degradation of PNNs in vitro [71,72] and following knockout or degradation of brain hyaluronan, the backbone component of PNNs, in neonatal and adult mice [73,74]. Interestingly, in experimental studies, loss of PNNs was reported to increase interneuron vulnerability to oxidative stress and cell death $[75,76]$. Given the established roles of oxidative stress in the evolution of neonatal brain injury, refs [7,77] loss of cortical PNNs may also contribute to the patterns of delayed interneuron cell death observed following neonatal HI. Collectively, these findings suggest that changes in 
cortical interneuron PNN expression may be an important component of interneuron dysfunction, seizure activity, and neurological disability following neonatal brain injury.

The exact mechanisms underlying the loss of interneurons and PNNs following term $\mathrm{HI}$ in the present study remain unclear. However, our findings of a marked reduction in interneuron cell death and PNN loss following treatment with a connexin 43 hemichannel inhibitor from $90 \mathrm{~min}$ to $25 \mathrm{~h}$ after recovery from cerebral ischemia suggests a potential role for opening of hemichannels. There are 21 known connexin hemichannel isoforms, although connexin 43 is the most highly expressed connexin in the brain and, as such, is a key connexin targeted for neuroprotection studies [78-80]. Abnormal opening of connexin hemichannels, including connexin43, following a range of CNS insults can result in spread of cellular injury through mechanisms involving loss of cellular membrane potential, abnormal calcium influx, and cell lysis as well as release of glutamate and cellular excitotoxicity [78,81-83]. Abnormal hemichannel opening is also associated with vascular disruption and hemorrhage $[84,85]$ as well as inflammation, in particular inflammasome activation leading to the release of inflammatory cytokines in the CNS and other tissues [86-90]. Further, N-methyl-D-aspartate-induced cellular excitotoxicity is exacerbated in the presence of inflammatory cytokines and increased connexin 43 hemichannel activity [91]. Thus, blockade of these pathogenic events with peptide 5 may have contributed to the survival of cortical interneurons after term $\mathrm{HI}$ in the present study [90].

Astrogliosis is a hallmark feature of perinatal brain injury $[90,92-94]$ and reactive astrocytes play a key role in the evolution of brain injury [95-98]. Connexin43 is the predominant gap junction protein expressed on astrocytes $[79,99,100]$ and the functions of astrocytes are controlled, at least in part, by connexin43 hemichannel signaling [18]. Critically, we and others reported that $\mathrm{HI}$ can trigger pathological opening of astrocytic connexin 43 hemichannels, leading to reactive astrocytosis, altered astrocytic function, oligodendrocyte loss, interneuron injury, and seizures [101-104], while connexin 43 hemichannel blockade using peptide 5 reduced these adverse effects [21,22,105-107].

With respect to the loss of PNNs observed following HI in the present study, under normal conditions, astrocytes play key physiological roles in the production and degradation of the ECM and PNNs via synthesis of proteoglycans and release of proteolytic enzymes [10,108-111]. However, changes in proteoglycan synthesis and excessive release of proteolytic enzymes by reactive astrocytes following injury can cause pathological ECM/PNN production/degradation [108,110,112-115]. For example, in preterm fetal sheep, HI was associated with increased hyaluronidase (degrades hyaluronan in ECM/PNNs) expression on reactive astrocytes from 1 day to 4 weeks recovery [116]. Similarly, rapid and persistent increases in expression of hyaluronidases, matrix metalloproteinases (e.g., MMP9; degrades chondroitin sulfate proteoglycans in ECM/PNNs $[10,117,118])$, and disintegrin and metalloproteinase with thromospondin motifs (degrade lecticans (e.g., aggrecan, brevican, versican, and neurocan) and phosphocan in ECM/PNNs $[10,111,117,119])$ with associated ECM disruption were reported following cerebral $\mathrm{HI}$ in neonatal $[62,65,120,121]$ and adult $[122-126]$ rodents. Comparable changes in various ECM proteases were reported in the plasma and/or brain following $\mathrm{HI}$ in human neonates [121,127] and stroke in human adults [128]. Further, experimental inhibition of ECM protease activity was reported to reduce neural injury following stroke in adult rodents [126,129]. Finally, in other tissues such as spinal cord injury, skin, and cornea of the eye wounds, connexin 43 hemichannel opening is associated with development of extracellular matrix fibrosis [130-132]. Thus, speculatively, pathological connexin 43 hemichannel-mediated astrocytosis after perinatal $\mathrm{HI}$ may result in aberrant ECM remodeling in the brain, including altered development and/or degradation of cortical PNNs. Conversely, inhibiting astrocytosis via connexin43 hemichannel blockade (e.g., see $[85,132-135])$ may prevent this ECM remodeling. Future studies examining changes in astrocytic proteoglycan synthesis and release of proteolytic enzymes with connexin 43 hemichannel blockade after perinatal $\mathrm{HI}$ are required to validate this hypothesis.

Of note, it is possible that hemichannels other than connexin 43 may contribute to evolution of brain injury following $\mathrm{HI}$ in the present study. For example, neuronal connexin 36 hemichannels were reported 
to release ATP in a model of spreading depression in cultured neurons [136]. Further, opening of neuronal pannexin 1 hemichannels following anoxia caused sustained depolarization and cell death in cultured hippocampal slices, $[137,138]$ while blocking pannexin 1 hemichannels was neuroprotective in adult rodent stroke models $[139,140]$. However, to our knowledge, there are no studies investigating the role of other hemichannels during recovery from perinatal ischemic brain injury. Importantly, peptide 5 was designed against the extracellular loop2 sequence of connexin43 [27], a region key for control of channel function, while the specificity of peptide 5 to connexin 43 over other connexin isoforms was recently validated [141]. Further, in vitro studies showed that peptide 5 selectively inhibits connexin hemichannels at concentrations as low as $5 \mu \mathrm{M}$, although high concentrations (e.g., $500 \mu \mathrm{M})$ can inhibit both hemichannels and gap junctions [27]. This is supported by in vivo studies showing that low doses of peptide 5 (such as that used in the present study) are protective [21] while high doses can exacerbate injury [32]. Similarly, cytoplasmic edema in spinal cords segments is reduced with concentrations of peptide 5 that block hemichannels but is not prevented at high peptide 5 concentrations, [27] indicating that the retention of cell-to-cell communication is necessary for full protective benefit of hemichannel blockade.

In conclusion, the present findings suggest that opening of connexin 43 hemichannels on astrocytes may contribute to the loss of interneurons, to deficits in interneuron PNNs, and to altered cortical inhibitory function, including delayed onset of seizures. Thus, targeting connexin 43 hemichannel opening and the resulting reactive astrocytosis, which is a hallmark of injury to the developing brain [92,93], may be a viable strategy to attenuate seizures, to prevent pathological ECM remodeling, and to improve cortical interneuron survival and function after $\mathrm{HI}$ in term born infants. Of note, we previously reported that connexin 43 hemichannel blockade could also reduce loss of striatal interneurons following $\mathrm{HI}$ in term fetal sheep [22]. Further, a reduction in interneuron loss in the cortex with erythropoietin treatment, [142] hippocampus with therapeutic hypothermia, [42] and striatum with bone marrow-derived mesenchymal stem cells [36] was reported following $\mathrm{HI}$ in neonatal rats and in the striatum with nitric oxide inhibition [33] or therapeutic hypothermia [143] following HI in preterm fetal sheep. Future studies are required to determine the exact timing of interneuron loss, altered PNN development, and expression of ECM remodeling enzymes after HI to help optimize treatment strategies.

\section{Materials and Methods}

\subsection{Animals and Surgery}

All procedures were approved by the Animal Ethics Committee of the University of Auckland (approval number 001942; 14 August 2017) and were performed in accordance with the New Zealand Animal Welfare Act 1999 and the University of Auckland's Code of Ethical Conduct for the use of animals for teaching and research, approved by the Ministry of Primary Industries, Government of New Zealand. This manuscript is compliant with the ARRIVE (Animal Research: Reporting of In Vivo Experiments) guidelines for reporting animal research [144].

Aseptic surgery was performed on time-mated Romney/Suffolk fetal sheep between 118-124 days of gestation (term is 145 days). Food but not water supply was stopped $18 \mathrm{~h}$ before surgery. Long acting oxytetracycline ( $20 \mathrm{mg} / \mathrm{kg}$; Phoenix Pharm, Auckland, New Zealand) was administered intramuscularly to ewes at $30 \mathrm{~min}$ before surgery. Anesthesia was initiated by intravenous administration of propofol (5 mg/kg; AstraZeneca Ltd., Auckland, New Zealand) and maintained using 2-3\% isoflurane in oxygen (Bomac Animal Health, Glendale, NSW, Australia). Ewes received intravenous infusion of isotonic saline at a rate of approximately $250 \mathrm{~mL} / \mathrm{h}$ to maintain fluid balance. The degree of anesthesia, maternal heart rate, and respiration were monitored during surgery.

The fetus was exposed after a maternal midline abdominal incision and polyvinyl catheters were inserted into the right and left fetal brachial arteries and amniotic cavity to measure mean arterial blood pressure. Electrocardiographic electrodes (AS633-3SSF; Cooner Wire, Chatsworth, CA, USA) were 
sewn across the fetal chest to record fetal heart rate. The vertebral-occipital anastomoses were ligated and inflatable carotid occluder cuffs were fixed around both carotid arteries [145,146]. Two pairs of EEG electrodes were fixed on the dura over the parasagittal parietal cortex $(10 \mathrm{~mm}$ and $20 \mathrm{~mm}$ anterior to bregma and $10 \mathrm{~mm}$ lateral) with cyanoacrylate glue. Two electrodes were sewn in the nuchal muscle and a reference electrode was sewn over the occiput to record fetal electromyographic activity. An intracerebroventricular catheter was inserted into the left lateral ventricle $(6 \mathrm{~mm}$ anterior and $4 \mathrm{~mm}$ lateral to bregma) for infusion of the mimetic peptide. Antibiotics ( $80 \mathrm{mg}$ gentamicin; Pharmacia and Upjohn, Rydalmere, NSW, Australia) were then administered into the amniotic sac before the uterus was closed. The maternal laparotomy skin incision received infiltration of $10 \mathrm{~mL} 0.5 \%$ bupivacaine plus adrenaline (AstraZeneca Ltd.) for local analgesia. The maternal long saphenous vein was catheterized to allow postoperative maternal treatment and euthanasia.

\subsection{Postoperative Care}

Sheep were kept in separate metabolic cages in a temperature-controlled room $\left(16 \pm 1^{\circ} \mathrm{C}\right.$, humidity $50 \pm 10 \%$ ) with ad libitum access to food and water and a $12 \mathrm{~h} \mathrm{light/dark} \mathrm{cycle.} \mathrm{Ewes} \mathrm{received}$ daily intravenous administration of antibiotics ( $600 \mathrm{mg}$ benzylpenicillin sodium and $80 \mathrm{mg}$ gentamicin; Novartis Ltd., Auckland, New Zealand) for 4 days. The maternal catheter was maintained patent by daily flushing and the fetal catheters were maintained by continuous infusion of heparinized saline $(20 \mathrm{U} / \mathrm{mL}$ at $0.15 \mathrm{~mL} / \mathrm{h})$.

\subsection{Experimental Protocols}

Fetuses were randomized to sham control $(n=8)$, cerebral ischemia (ischemia + vehicle; $n=10$ ), and cerebral ischemia + mimetic peptide 5 treatment (ischemia + peptide; $n=5$ ) groups. At $128 \pm 1$ days of gestation, cerebral ischemia was induced by reversible inflation of the bilateral carotid occluder cuffs for $30 \mathrm{~min}$ with saline. Successful occlusion was confirmed by a suppression of EEG activity within $30 \mathrm{~s}$ of inflation. Carotid artery occlusion was not performed on sham control animals.

At $90 \mathrm{~min}$ after the end of occlusion, animals in the ischemia + peptide group received an intracerebroventricular infusion of a mimetic peptide (Peptide 5; H-Val-Asp-Cys-Phe-Leu-Ser-Arg-Pro-Thr-Glu-Lys-Thr-OH; Auspep, Tullamarine, Australia) dissolved in artificial cerebrospinal fluid at $50 \mu \mathrm{mol} / \mathrm{kg} / \mathrm{h}$ for $1 \mathrm{~h}$ and at $50 \mu \mathrm{mol} / \mathrm{kg} / 24 \mathrm{~h}$ for the next $24 \mathrm{~h}$ (infusion rate of $1 \mathrm{~mL} / \mathrm{h}$ ). Peptide 5 interacts with the extracellular loop of connexin 43 to block connexin 43 hemichannel activity [27]. The sham control and ischemia + vehicle groups received vehicle infusion of artificial cerebrospinal fluid. Continuous fetal EEG recordings began $24 \mathrm{~h}$ before bilateral carotid artery occlusion and continued through the whole course of the experiment. The animals were euthanized at 7 days after $\mathrm{HI}$ and the brains were removed, weighed, and processed.

\subsection{Tissue Preparation}

Preparation of the fetal sheep brains was performed as previously described [17,21]. In brief, postmortem fetal sheep brains were perfusion fixed in 10\% phosphate-buffered formalin and embedded in paraffin. Coronal sections $(10-\mu \mathrm{m}$ thick) were cut using a microtome (Leica Jung RM2035; Leica Microsystems, Auckland, New Zealand). Two adjacent sections at the level of the mid-striatum [147] were selected from each animal for each analysis.

\subsection{Immunohistochemical Staining}

Immunohistochemical staining was performed as previously reported [17]. All washes were performed for $3 \times 5 \mathrm{~min}$ in $0.1 \mathrm{M}$ phosphate buffered saline (PBS). All primary and secondary antibodies were diluted with 3\% normal goat serum (NGS)/PBS unless otherwise stated. For brightfield immunohistochemistry, sections were de-paraffinized in $2 \times 15$ min xylene and then rehydrated in a series of ethanol solutions (100\%, 90\%, and $75 \% ; 5 \mathrm{~min}$ each), followed by $3 \times 5 \mathrm{~min}$ PBS washes. Antigen retrieval was performed in $10 \mathrm{mM}$ citrate buffer using the Antigen 200 Retriever 
(Electron Microscopy Sciences, Emgrid, SA, Australia) and the sections were washed in $3 \times 5 \mathrm{~min}$ PBS. Endogenous peroxidase activity was blocked by incubating the tissue sections in $1 \%$ hydrogen peroxide in methanol. Sections were then washed in $3 \times 5 \mathrm{~min}$ PBS, blocked in 5\% NGS/PBS for $1 \mathrm{~h}$ at room temperature, and incubated in primary antibodies (Table 1 ) overnight at $4{ }^{\circ} \mathrm{C}$. After washing in $3 \times 5$ min PBS, sections were incubated with biotinylated goat anti-rabbit or goat anti-mouse secondary antibodies (Table 1 ) for $3 \mathrm{~h}$ at room temperature, washed in $3 \times 5 \mathrm{~min}$ PBS, and then incubated in ExtrAvidin-Peroxidase (Sigma-Aldrich Co., Saint Louis, MO, USA) diluted in PBS for $2 \mathrm{~h}$ at room temperature. Sections were washed in $3 \times 5 \mathrm{~min}$ PBS and incubated in 3,3'-diaminobenzidine tetrahydrochloride hydrate (DAB; Sigma-Aldrich Co.) solution to generate a brown DAB reaction product before the reaction was stopped by washing in distilled water. Sections were then dehydrated in a series of ethanol solutions ( $75 \%, 90 \%$, and $100 \% ; 5$ min each), followed by $2 \times 10$ min xylene. Slides were then cover-slipped with DPX mounting media (Sigma-Aldrich Co.).

Table 1. Antibodies and markers used for immunohistochemistry.

\begin{tabular}{cccc}
\hline Antibody & Dilution & Specificity & Source \\
\hline $\begin{array}{c}\text { Primary Antibodies } \\
\text { Gamma-aminobutyric acid 65/67 }\end{array}$ & $1: 200$ & $\begin{array}{c}\text { GABAergic interneurons } \\
\text { Parvalbumin }\end{array}$ & $\begin{array}{c}\text { Abcam, Melbourne, Australia } \\
\text { Calretinin }\end{array}$ \\
$\begin{array}{c}\text { Calbindin } \\
\text { Calretinin interneurons }\end{array}$ & $\begin{array}{c}\text { Swant Ltd., Marly, Switzerland } \\
\text { Swant Ltd. } \\
\text { Swant Ltd. }\end{array}$ \\
$\begin{array}{c}\text { Calbindin interneurons } \\
\text { agglutinin }\end{array}$ & $1: 200$ & Perineuronal nets & $\begin{array}{c}\text { Sigma-Aldrich Co., Saint } \\
\text { Louis, MO, USA }\end{array}$ \\
NeuN & $1: 200$ & Post-mitotic neurons & Merck Millipore, Billerica, \\
MA, USA
\end{tabular}

For fluorescent immunohistochemistry, sections were deparaffinized, rehydrated, antigen retrieved, and blocked with 5\% NGS as described above. Sections were then incubated in $0.1 \%$ avidin/PBS and $0.1 \%$ biotin/PBS for 15 min each to block endogenous biotin. Next, sections were incubated with biotinylated WFA (labels the $\mathrm{N}$-acetylgalactosamine of the glycoconjugates enriched in PNNs [148,149]), rabbit anti-GAD65/67, and mouse anti-NeuN antibodies (Table 1) for 3 nights at $4{ }^{\circ} \mathrm{C}$, washed in $3 \times 5 \mathrm{~min}$ PBS, and then incubated in streptavidin-conjugated IgG Alexa Fluor 594, goat anti-rabbit IgG Alexa Fluor 488, and goat anti-mouse IgG1 Alexa Fluor 647 secondary antibodies (Table 1) and Hoechst 33258 (1:10,000; Thermo Fisher Scientific, Waltham, MA, USA) for $2.5 \mathrm{~h}$ at room temperature. Slides were then washed and cover-slipped using Vectashield mounting medium (Vector Laboratories, Burlingame, CA, USA).

\subsection{Image Analysis}

The methods for image analysis were previously described [17]. All quantification was performed by assessors (T.M.F. and P.Y.) blinded to the treatment groups. Imaging software (Stereo Investigator; MBF Bioscience, Williston, VT, USA) connected to a microscope (Zeiss AxioImager M2; Carl Zeiss Microscopy, LLC, Thornwood, NY, USA) equipped with a motorized stage (MAC 6000; MBF Bioscience) was used to trace the first and second parasagittal gyri of the right hemisphere of each brain section at $2.5 \times$ objective (Figure 5). The numbers of DAB-labelled $\mathrm{GAD}^{+}$, parvalbumin ${ }^{+}$, calretinin ${ }^{+}$, and calbindin ${ }^{+}$neurons in all layers of the parasagittal cortex in both gyri were counted by transmitted light microscopy using the fractionator probe (40× objective; grid size: $500 \times 500 \mu \mathrm{m}$; counting frame size: $150 \times 150 \mu \mathrm{m}$; approximately 60 sites per gyrus). Positive cells were selected based on a typical pattern of cytoplasm staining and cellular morphology (c.f. control neurons in Figure 2) [22]. Note that 
cells with condensed cytoplasmic aggregates of $\mathrm{GAD}^{+}$, parvalbumin ${ }^{+}$, calretinin ${ }^{+}$, or calbindin ${ }^{+}$ staining (indicative of injured cells) were excluded from analysis. The neuronal densities (cell number $/ \mathrm{mm}^{2}$ ) in the parasagittal cortex were calculated and two slides per animal were averaged to obtain the final data.

For quantification of fluorescently labelled $\mathrm{WFA}^{+}$and $\mathrm{GAD}^{+}$neurons by reflected fluorescence microscopy, the dense WFA immunoreactive layer (layer 6) in the parasagittal cortex was traced as described above ( $5 \times$ objective) using WFA, NeuN, and Hoechst labelling as guides (Figure 5 ), as we reported [17]. The numbers of $\mathrm{WFA}^{+}, \mathrm{GAD}^{+}$, and $\mathrm{WFA}^{+} / \mathrm{GAD}^{+}$neurons in this layer were counted (40× objective; grid size: $500 \times 500 \mu \mathrm{m}$; counting frame size: $100 \times 100 \mu \mathrm{m}$; approximately 25 sites per gyrus) for each gyrus. The neuronal densities and percentage of $\mathrm{WFA}^{+} / \mathrm{GAD}^{+}$neurons for each animal were calculated by averaging the density and percentage values of the two sections per animal.

\subsection{Data Analysis}

EEG data processing was performed using LabVIEW software (LabVIEW for Windows, National Instruments Inc., Austin, TX, USA). Seizures were recognized visually as sudden repetitive and evolving waveforms in the EEG signal lasting $>10 \mathrm{~s}$ with an amplitude $>20 \mu \mathrm{V}$ [150]. Note that all physiological data from animals used in this study were previously reported [21,151]. The differences in neuronal cell densities between sham control, ischemia + vehicle, and ischemia + peptide groups were analyzed by one-way analysis of variance (ANOVA), followed by Fisher's LSD test for post hoc analysis. Note that, for some animals, tissue sections for DAB staining of interneuron markers were not available because of technical reasons (see figure legends for specific animal numbers). The relationship between seizure burden and interneuron/PNN densities was examined by nonlinear regression with a sigmoidal curve fit and automatic outlier detection and elimination. $p<0.05$ was considered statistically significant. All statistical analyses were performed using statistical software (GraphPad Prism v7.03; La Jolla, CA, USA). Data are presented as mean \pm standard error of the mean.

Author Contributions: P.Y. and J.M.D. conceptualized and designed the study. R.G., J.O.D., G.W., A.J.G. and L.B. performed sheep surgeries, experiments, and care. P.Y. and T.M.F. performed immunohistochemistry, cell counts, imaging, and analysis. R.G. undertook immunohistochemistry and seizure analysis. P.Y. and J.M.D. wrote the main manuscript text. A.J.G., L.B. and C.R.G. provided overall oversight of the research. R.N.K., J.D.P. and S.R. provided critical review of the manuscript and laboratory support. All authors critically reviewed the manuscript and approved the final manuscript as submitted and agree to be accountable for all aspects of the work.

Funding: This study was supported by the Health Research Council of New Zealand (grants 17/601 \& 20/101), Cure Kids NZ (grant 3566), and the CJ Martin Early Career Fellowship from the National Health and Medical Research Council of Australia (grant 1090890).

Acknowledgments: The authors thank Rani Wilson and Vaho Maisashvili for technical assistance.

Conflicts of Interest: The authors declare no conflict of interest. The funding sources had no role in the study design, collection, analysis, and interpretation of the data or writing of this report.

\section{References}

1. Vannucci, R.C. Hypoxic-ischemic encephalopathy. Am. J. Perinatol. 2000, 17, 113-120. [CrossRef] [PubMed]

2. Le Magueresse, C.; Monyer, H. GABAergic interneurons shape the functional maturation of the cortex. Neuron 2013, 77, 388-405. [CrossRef] [PubMed]

3. Tau, G.Z.; Peterson, B.S. Normal development of brain circuits. Neuropsychopharmacology 2010, 35, 147-168. [CrossRef] [PubMed]

4. Kwon, S.H.; Scheinost, D.; Lacadie, C.; Benjamin, J.; Myers, E.H.; Qiu, M.; Schneider, K.C.; Rothman, D.L.; Constable, R.T.; Ment, L.R. GABA, resting-state connectivity and the developing brain. Neonatology 2014, 106, 149-155. [CrossRef] [PubMed]

5. Lewis, D.A. Inhibitory neurons in human cortical circuits: Substrate for cognitive dysfunction in schizophrenia. Curr. Opin. Neurobiol. 2014, 26, 22-26. [CrossRef]

6. Jacob, J. Cortical interneuron dysfunction in epilepsy associated with autism spectrum disorders. Epilepsia 2016, 57, 182-193. [CrossRef] 
7. Robinson, S.; Li, Q.; Dechant, A.; Cohen, M.L. Neonatal loss of gamma-aminobutyric acid pathway expression after human perinatal brain injury. J. Neurosurg. 2006, 104 (Suppl. 6), 396-408.

8. Smith-Hicks, C.L. GABAergic dysfunction in pediatric neuro-developmental disorders. Front. Cell. Neurosci. 2013, 7, 269. [CrossRef]

9. Celio, M.R.; Blumcke, I. Perineuronal nets-A specialized form of extracellular matrix in the adult nervous system. Brain Res. Rev. 1994, 19, 128-145. [CrossRef]

10. Bozzelli, P.L.; Alaiyed, S.; Kim, E.; Villapol, S.; Conant, K. Proteolytic remodeling of perineuronal nets: Effects on synaptic plasticity and neuronal population dynamics. Neural. Plast. 2018, 2018, 5735789.

11. Wen, T.H.; Binder, D.K.; Ethell, I.M.; Razak, K.A. The perineuronal 'safety' net? Perineuronal net abnormalities in neurological disorders. Front. Mol. Neurosci. 2018, 11, 270. [CrossRef] [PubMed]

12. Hockfield, S.; Kalb, R.G.; Zaremba, S.; Fryer, H. Expression of neural proteoglycans correlates with the acquisition of mature neuronal properties in the mammalian brain. Cold Spring Harb. Symp. Quant. Biol. 1990, 55, 505-514. [CrossRef]

13. Testa, D.; Prochiantz, A.; Di Nardo, A.A. Perineuronal nets in brain physiology and disease. Semin. Cell Dev. Biol. 2019, 89, 125-135. [CrossRef] [PubMed]

14. Bitanihirwe, B.K.Y.; Mauney, S.A.; Woo, T.U.W. Weaving a net of neurobiological mechanisms in schizophrenia and unraveling the underlying pathophysiology. Biol. Psychiatry 2016, 80, 589-598. [CrossRef]

15. Morawski, M.; Bruckner, G.; Jager, C.; Seeger, G.; Matthews, R.T.; Arendt, T. Involvement of perineuronal and perisynaptic extracellular matrix in Alzheimer's disease neuropathology. Brain Pathol. 2012, 22, 547-561. [CrossRef]

16. McRae, P.A.; Baranov, E.; Rogers, S.L.; Porter, B.E. Persistent decrease in multiple components of the perineuronal net following status epilepticus. Eur. J. Neurosci. 2012, 36, 3471-3482. [CrossRef] [PubMed]

17. Fowke, T.M.; Galinsky, R.; Davidson, J.O.; Wassink, G.; Karunasinghe, R.N.; Prasad, J.D.; Bennet, L.; Gunn, A.J.; Dean, J.M. Loss of interneurons and disruption of perineuronal nets in the cerebral cortex following hypoxia-ischaemia in near-term fetal sheep. Sci. Rep. 2018, 8, 17686. [CrossRef] [PubMed]

18. Decrock, E.; De Vuyst, E.; Vinken, M.; Van Moorhem, M.; Vranckx, K.; Wang, N.; Van Laeken, L.; De Bock, M.; D'Herde, K.; Lai, C.P.; et al. Connexin 43 hemichannels contribute to the propagation of apoptotic cell death in a rat C6 glioma cell model. Cell Death Differ. 2009, 16, 151-163. [CrossRef]

19. Nadarajah, B.; Thomaidou, D.; Evans, W.H.; Parnavelas, J.G. Gap junctions in the adult cerebral cortex: Regional differences in their distribution and cellular expression of connexins. J. Comp. Neurol. 1996, 376, 326-342. [CrossRef]

20. Nakase, T.; Yoshida, Y.; Nagata, K. Enhanced connexin 43 immunoreactivity in penumbral areas in the human brain following ischemia. Glia 2006, 54, 369-375. [CrossRef]

21. Davidson, J.O.; Green, C.R.; Nicholson, L.F.; O'Carroll, S.J.; Fraser, M.; Bennet, L.; Gunn, A.J. Connexin hemichannel blockade improves outcomes in a model of fetal ischemia. Ann. Neurol. 2012, 71, 121-132. [CrossRef] [PubMed]

22. Galinsky, R.; Davidson, J.O.; Lear, C.A.; Bennet, L.; Green, C.R.; Gunn, A.J. Connexin hemichannel blockade improves survival of striatal GABA-ergic neurons after global cerebral ischaemia in term-equivalent fetal sheep. Sci. Rep. 2017, 7, 6304. [CrossRef] [PubMed]

23. McIntosh, G.H.; Baghurst, K.I.; Potter, B.J.; Hetzel, B.S. Foetal brain development in the sheep. Neuropathol. Appl. Neurobiol. 1979, 5, 103-114. [CrossRef]

24. Dobbing, J.; Sands, J. Timing of neuroblast multiplication in developing human brain. Nature 1970, 226, 639-640. [CrossRef] [PubMed]

25. Stolp, H.B.; Fleiss, B.; Arai, Y.; Supramaniam, V.; Vontell, R.; Birtles, S.; Yates, A.G.; Baburamani, A.A.; Thornton, C.; Rutherford, M.; et al. Interneuron development is disrupted in preterm brains with diffuse white matter injury: Observations in mouse and human. Front. Physiol. 2019, 10, 955. [CrossRef] [PubMed]

26. Saito, M.; Smiley, J.F.; Hui, M.; Masiello, K.; Betz, J.; Ilina, M.; Saito, M.; Wilson, D.A. Neonatal ethanol disturbs the normal maturation of parvalbumin interneurons surrounded by subsets of perineuronal nets in the cerebral cortex: Partial reversal by lithium. Cereb. Cortex 2019, 29, 1383-1397. [CrossRef]

27. O'Carroll, S.J.; Alkadhi, M.; Nicholson, L.F.; Green, C.R. Connexin 43 mimetic peptides reduce swelling, astrogliosis, and neuronal cell death after spinal cord injury. Cell Commun. Adhes. 2008, 15, 27-42. [CrossRef] 
28. Chacko, A.; Andronikou, S.; Mian, A.; Goncalves, F.G.; Vedajallam, S.; Thai, N.J. Cortical ischaemic patterns in term partial-prolonged hypoxic-ischaemic injury-the inter-arterial watershed demonstrated through atrophy, ulegyria and signal change on delayed MRI scans in children with cerebral palsy. Insights Imaging 2020, 11, 53. [CrossRef]

29. Ahearne, C.E.; Boylan, G.B.; Murray, D.M. Short and long term prognosis in perinatal asphyxia: An update. World J. Clin. Pediatr. 2016, 5, 67-74. [CrossRef]

30. Villani, F.; D’Incerti, L.; Granata, T.; Battaglia, G.; Vitali, P.; Chiapparini, L.; Avanzini, G. Epileptic and imaging findings in perinatal hypoxic-ischemic encephalopathy with ulegyria. Epilepsy Res. 2003, 55, $235-243$. [CrossRef]

31. Ouwehand, S.; Smidt, L.C.A.; Dudink, J.; Benders, M.; de Vries, L.S.; Groenendaal, F.; van der Aa, N.E. Predictors of outcomes in hypoxic-ischemic encephalopathy following hypothermia: A meta-analysis. Neonatology 2020, 1-17. [CrossRef]

32. Davidson, J.O.; Green, C.R.; Nicholson, L.F.; Bennet, L.; Gunn, A.J. Deleterious effects of high dose connexin 43 mimetic peptide infusion after cerebral ischaemia in near-term fetal sheep. Int. J. Mol. Sci. 2012, 13, 6303-6319. [CrossRef] [PubMed]

33. Drury, P.P.; Davidson, J.O.; Mathai, S.; van den Heuij, L.G.; Ji, H.; Bennet, L.; Tan, S.; Silverman, R.B.; Gunn, A.J. nNOS inhibition during profound asphyxia reduces seizure burden and improves survival of striatal phenotypic neurons in preterm fetal sheep. Neuropharmacology 2014, 83, 62-70. [CrossRef] [PubMed]

34. McClendon, E.; Chen, K.; Gong, X.; Sharifnia, E.; Hagen, M.; Cai, V.; Shaver, D.C.; Riddle, A.; Dean, J.M.; Gunn, A.J.; et al. Prenatal cerebral ischemia triggers dysmaturation of caudate projection neurons. Ann. Neurol. 2014, 75, 508-524. [CrossRef] [PubMed]

35. Ardalan, M.; Svedin, P.; Baburamani, A.A.; Supramaniam, V.G.; Ek, J.; Hagberg, H.; Mallard, C. Dysmaturation of somatostatin interneurons following umbilical cord occlusion in preterm fetal sheep. Front. Physiol. 2019, 10, 563. [CrossRef]

36. Cameron, S.H.; Alwakeel, A.J.; Goddard, L.; Hobbs, C.E.; Gowing, E.K.; Barnett, E.R.; Kohe, S.E.; Sizemore, R.J.; Oorschot, D.E. Delayed post-treatment with bone marrow-derived mesenchymal stem cells is neurorestorative of striatal medium-spiny projection neurons and improves motor function after neonatal rat hypoxia-ischemia. Mol. Cell. Neurosci. 2015, 68, 56-72. [CrossRef]

37. Lacaille, H.; Vacher, C.M.; Bakalar, D.; O’Reilly, J.J.; Salzbank, J.; Penn, A.A. Impaired interneuron development in a novel model of neonatal brain injury. eNeuro 2019, 6. [CrossRef]

38. Louzoun-Kaplan, V.; Zuckerman, M.; Perez-Polo, J.R.; Golan, H.M. Prenatal hypoxia down regulates the GABA pathway in newborn mice cerebral cortex; partial protection by $\mathrm{MgSO}_{4}$. Int. J. Dev. Neurosci. 2008, 26, 77-85. [CrossRef]

39. Van de Berg, W.D.; Kwaijtaal, M.; de Louw, A.J.; Lissone, N.P.; Schmitz, C.; Faull, R.L.; Blokland, A.; Blanco, C.E.; Steinbusch, H.W. Impact of perinatal asphyxia on the GABAergic and locomotor system. Neuroscience 2003, 117, 83-96. [CrossRef]

40. Nisimov, H.; Orenbuch, A.; Pleasure, S.J.; Golan, H.M. Impaired organization of GABAergic neurons following prenatal hypoxia. Neuroscience 2018, 384, 300-313. [CrossRef]

41. Failor, S.; Nguyen, V.; Darcy, D.P.; Cang, J.; Wendland, M.F.; Stryker, M.P.; McQuillen, P.S. Neonatal cerebral hypoxia-ischemia impairs plasticity in rat visual cortex. J. Neurosci. 2010, 30, 81-92. [CrossRef] [PubMed]

42. Chavez-Valdez, R.; Emerson, P.; Goffigan-Holmes, J.; Kirkwood, A.; Martin, L.J.; Northington, F.J. Delayed injury of hippocampal interneurons after neonatal hypoxia-ischemia and therapeutic hypothermia in a murine model. Hippocampus 2018, 28, 617-630. [CrossRef] [PubMed]

43. Komitova, M.; Xenos, D.; Salmaso, N.; Tran, K.M.; Brand, T.; Schwartz, M.L.; Ment, L.; Vaccarino, F.M. Hypoxia-induced developmental delays of inhibitory interneurons are reversed by environmental enrichment in the postnatal mouse forebrain. J. Neurosci. 2013, 33, 13375-13387. [CrossRef] [PubMed]

44. Verney, C.; Rees, S.; Biran, V.; Thompson, M.; Inder, T.; Gressens, P. Neuronal damage in the preterm baboon: Impact of the mode of ventilatory support. J. Neuropathol. Exp. Neurol. 2010, 69, 473-482. [CrossRef]

45. Panda, S.; Dohare, P.; Jain, S.; Parikh, N.; Singla, P.; Mehdizadeh, R.; Klebe, D.W.; Kleinman, G.M.; Cheng, B.; Ballabh, P. Estrogen treatment reverses prematurity-induced disruption in cortical interneuron population. J. Neurosci. 2018, 38, 7378-7391. [CrossRef] 
46. Tibrewal, M.; Cheng, B.; Dohare, P.; Hu, F.; Mehdizadeh, R.; Wang, P.; Zheng, D.; Ungvari, Z.; Ballabh, P. Disruption of interneuron neurogenesis in premature newborns and reversal with estrogen treatment. J. Neurosci. 2018, 38, 1100-1113. [CrossRef]

47. Katsarou, A.M.; Moshe, S.L.; Galanopoulou, A.S. Interneuronopathies and their role in early life epilepsies and neurodevelopmental disorders. Epilepsia Open 2017, 2, 284-306. [CrossRef]

48. Galanopoulou, A.S. GABA(A) receptors in normal development and seizures: Friends or foes? Curr. Neuropharmacol. 2008, 6, 1-20. [CrossRef]

49. Lewis, D.A.; Moghaddam, B. Cognitive dysfunction in schizophrenia: Convergence of gamma-aminobutyric acid and glutamate alterations. Arch. Neurol. 2006, 63, 1372-1376. [CrossRef]

50. Morishita, H.; Kundakovic, M.; Bicks, L.; Mitchell, A.; Akbarian, S. Interneuron epigenomes during the critical period of cortical plasticity: Implications for schizophrenia. Neurobiol. Learn. Mem. 2015, 124, 104-110. [CrossRef]

51. Powell, E.M.; Campbell, D.B.; Stanwood, G.D.; Davis, C.; Noebels, J.L.; Levitt, P. Genetic disruption of cortical interneuron development causes region- and GABA cell type-specific deficits, epilepsy, and behavioral dysfunction. J. Neurosci. 2003, 23, 622-631. [CrossRef] [PubMed]

52. Botting, N.; Powls, A.; Cooke, R.W.; Marlow, N. Attention deficit hyperactivity disorders and other psychiatric outcomes in very low birthweight children at 12 years. J. Child. Psychol. Psychiatry 1997, 38, 931-941. [CrossRef] [PubMed]

53. Indredavik, M.S.; Vik, T.; Evensen, K.A.; Skranes, J.; Taraldsen, G.; Brubakk, A.M. Perinatal risk and psychiatric outcome in adolescents born preterm with very low birth weight or term small for gestational age. J. Dev. Behav. Pediatr. 2010, 31, 286-294. [CrossRef] [PubMed]

54. Barnes, S.A.; Pinto-Duarte, A.; Kappe, A.; Zembrzycki, A.; Metzler, A.; Mukamel, E.A.; Lucero, J.; Wang, X.; Sejnowski, T.J.; Markou, A.; et al. Disruption of mGluR5 in parvalbumin-positive interneurons induces core features of neurodevelopmental disorders. Mol. Psychiatry 2015, 20, 1161-1172. [CrossRef]

55. Wohr, M.; Orduz, D.; Gregory, P.; Moreno, H.; Khan, U.; Vorckel, K.J.; Wolfer, D.P.; Welzl, H.; Gall, D.; Schiffmann, S.N.; et al. Lack of parvalbumin in mice leads to behavioral deficits relevant to all human autism core symptoms and related neural morphofunctional abnormalities. Transl. Psychiatry 2015, 5, e525. [CrossRef]

56. Lim, L.; Mi, D.; Llorca, A.; Marin, O. Development and functional diversification of cortical interneurons. Neuron 2018, 100, 294-313. [CrossRef]

57. Letinic, K.; Zoncu, R.; Rakic, P. Origin of GABAergic neurons in the human neocortex. Nature 2002, 417, 645-649. [CrossRef]

58. Luhmann, H.J.; Kirischuk, S.; Sinning, A.; Kilb, W. Early GABAergic circuitry in the cerebral cortex. Curr. Opin. Neurobiol. 2014, 26, 72-78. [CrossRef]

59. Pyka, M.; Wetzel, C.; Aguado, A.; Geissler, M.; Hatt, H.; Faissner, A. Chondroitin sulfate proteoglycans regulate astrocyte-dependent synaptogenesis and modulate synaptic activity in primary embryonic hippocampal neurons. Eur. J. Neurosci. 2011, 33, 2187-2202. [CrossRef]

60. Zaremba, S.; Guimaraes, A.; Kalb, R.G.; Hockfield, S. Characterization of an activity-dependent, neuronal surface proteoglycan identified with monoclonal antibody Cat-301. Neuron 1989, 2, 1207-1219. [CrossRef]

61. Frischknecht, R.; Chang, K.J.; Rasband, M.N.; Seidenbecher, C.I. Neural ECM molecules in axonal and synaptic homeostatic plasticity. Prog. Brain Res. 2014, 214, 81-100. [PubMed]

62. Srivastava, T.; Diba, P.; Dean, J.M.; Banine, F.; Shaver, D.; Hagen, M.; Gong, X.; Su, W.; Emery, B.; Marks, D.L.; et al. A TLR/AKT/FoxO3 immune tolerance-like pathway disrupts the repair capacity of oligodendrocyte progenitors. J. Clin. Investig. 2018, 128, 2025-2041. [CrossRef] [PubMed]

63. Matsui, F.; Kakizawa, H.; Nishizuka, M.; Hirano, K.; Shuo, T.; Ida, M.; Tokita, Y.; Aono, S.; Keino, H.; Oohira, A. Changes in the amounts of chondroitin sulfate proteoglycans in rat brain after neonatal hypoxia-ischemia. J. Neurosci. Res. 2005, 81, 837-845. [CrossRef]

64. Aya-ay, J.; Mayer, J.; Eakin, A.K.; Muffly, B.G.; Anello, M.; Sandy, J.D.; Gottschall, P.E. The effect of hypoxic-ischemic brain injury in perinatal rats on the abundance and proteolysis of brevican and NG2. Exp. Neurol. 2005, 193, 149-162. [CrossRef]

65. Leonardo, C.C.; Eakin, A.K.; Ajmo, J.M.; Gottschall, P.E. Versican and brevican are expressed with distinct pathology in neonatal hypoxic-ischemic injury. J. Neurosci. Res. 2008, 86, 1106-1114. [CrossRef] [PubMed] 
66. Karetko-Sysa, M.; Skangiel-Kramska, J.; Nowicka, D. Disturbance of perineuronal nets in the perilesional area after photothrombosis is not associated with neuronal death. Exp. Neurol. 2011, 231, 113-126. [CrossRef]

67. Yutsudo, N.; Kitagawa, H. Involvement of chondroitin 6-sulfation in temporal lobe epilepsy. Exp. Neurol. 2015, 274, 126-133. [CrossRef]

68. Pollock, E.; Everest, M.; Brown, A.; Poulter, M.O. Metalloproteinase inhibition prevents inhibitory synapse reorganization and seizure genesis. Neurobiol. Dis. 2014, 70, 21-31. [CrossRef]

69. Hobohm, C.; Gunther, A.; Grosche, J.; Rossner, S.; Schneider, D.; Bruckner, G. Decomposition and long-lasting downregulation of extracellular matrix in perineuronal nets induced by focal cerebral ischemia in rats. J. Neurosci. Res. 2005, 80, 539-548. [CrossRef]

70. Hartig, W.; Mages, B.; Aleithe, S.; Nitzsche, B.; Altmann, S.; Barthel, H.; Krueger, M.; Michalski, D. Damaged neocortical perineuronal nets due to experimental focal cerebral ischemia in mice, rats and sheep. Front. Integr. Neurosci. 2017, 11, 15. [CrossRef]

71. Dityatev, A.; Bruckner, G.; Dityateva, G.; Grosche, J.; Kleene, R.; Schachner, M. Activity-dependent formation and functions of chondroitin sulfate-rich extracellular matrix of perineuronal nets. Dev. Neurobiol. 2007, 67, 570-588. [CrossRef]

72. Vedunova, M.; Sakharnova, T.; Mitroshina, E.; Perminova, M.; Pimashkin, A.; Zakharov, Y.; Dityatev, A.; Mukhina, I. Seizure-like activity in hyaluronidase-treated dissociated hippocampal cultures. Front. Cell. Neurosci. 2013, 7, 149. [CrossRef]

73. Balashova, A.; Pershin, V.; Zaborskaya, O.; Tkachenko, N.; Mironov, A.; Guryev, E.; Kurbatov, L.; Gainullin, M.; Mukhina, I. Enzymatic digestion of hyaluronan-based brain extracellular matrix in vivo can induce seizures in neonatal mice. Front. Neurosci. 2019, 13, 1033. [CrossRef] [PubMed]

74. Arranz, A.M.; Perkins, K.L.; Irie, F.; Lewis, D.P.; Hrabe, J.; Xiao, F.; Itano, N.; Kimata, K.; Hrabetova, S.; Yamaguchi, Y. Hyaluronan deficiency due to Has3 knock-out causes altered neuronal activity and seizures via reduction in brain extracellular space. J. Neurosci. 2014, 34, 6164-6176. [CrossRef]

75. Suttkus, A.; Rohn, S.; Jager, C.; Arendt, T.; Morawski, M. Neuroprotection against iron-induced cell death by perineuronal nets-An in vivo analysis of oxidative stress. Am. J. Neurodegener. Dis. 2012, 1, 122-129. [PubMed]

76. Cabungcal, J.H.; Steullet, P.; Morishita, H.; Kraftsik, R.; Cuenod, M.; Hensch, T.K.; Do, K.Q. Perineuronal nets protect fast-spiking interneurons against oxidative stress. Proc. Natl. Acad. Sci. USA 2013, 110, 9130-9135. [CrossRef] [PubMed]

77. Placha, K.; Luptakova, D.; Baciak, L.; Ujhazy, E.; Juranek, I. Neonatal brain injury as a consequence of insufficient cerebral oxygenation. Neuro. Endocrinol. Lett. 2016, 37, 79-96. [PubMed]

78. Davidson, J.O.; Green, C.R.; Bennet, L.; Nicholson, L.F.; Danesh-Meyer, H.; O'Carroll, S.J.; Gunn, A.J. A key role for connexin hemichannels in spreading ischemic brain injury. Curr. Drug Targets 2013, 14, $36-46$. [CrossRef]

79. Schulz, R.; Gorge, P.M.; Gorbe, A.; Ferdinandy, P.; Lampe, P.D.; Leybaert, L. Connexin 43 is an emerging therapeutic target in ischemia/reperfusion injury, cardioprotection and neuroprotection. Pharmacol. Ther. 2015, 153, 90-106. [CrossRef]

80. Leybaert, L.; Lampe, P.D.; Dhein, S.; Kwak, B.R.; Ferdinandy, P.; Beyer, E.C.; Laird, D.W.; Naus, C.C.; Green, C.R.; Schulz, R. Connexins in cardiovascular and neurovascular health and disease: Pharmacological implications. Pharmacol. Rev. 2017, 69, 396-478. [CrossRef]

81. Kang, J.; Kang, N.; Lovatt, D.; Torres, A.; Zhao, Z.; Lin, J.; Nedergaard, M. Connexin 43 hemichannels are permeable to ATP. J. Neurosci. 2008, 28, 4702-4711. [CrossRef] [PubMed]

82. Ye, Z.C.; Wyeth, M.S.; Baltan-Tekkok, S.; Ransom, B.R. Functional hemichannels in astrocytes: A novel mechanism of glutamate release. J. Neurosci. 2003, 23, 3588-3596. [CrossRef] [PubMed]

83. Belousov, A.B.; Fontes, J.D.; Freitas-Andrade, M.; Naus, C.C. Gap junctions and hemichannels: Communicating cell death in neurodevelopment and disease. BMC Cell Biol. 2017, 18 (Suppl. 1), 4. [CrossRef] [PubMed]

84. De Bock, M.; Culot, M.; Wang, N.; Bol, M.; Decrock, E.; De Vuyst, E.; da Costa, A.; Dauwe, I.; Vinken, M.; Simon, A.M.; et al. Connexin channels provide a target to manipulate brain endothelial calcium dynamics and blood-brain barrier permeability. J. Cereb. Blood Flow Metab. 2011, 31, 1942-1957. [CrossRef] 
85. Danesh-Meyer, H.V.; Kerr, N.M.; Zhang, J.; Eady, E.K.; O'Carroll, S.J.; Nicholson, L.F.; Johnson, C.S.; Green, C.R. Connexin43 mimetic peptide reduces vascular leak and retinal ganglion cell death following retinal ischaemia. Brain 2012, 135, 506-520. [CrossRef]

86. Mugisho, O.O.; Green, C.R.; Kho, D.T.; Zhang, J.; Graham, E.S.; Acosta, M.L.; Rupenthal, I.D. The inflammasome pathway is amplified and perpetuated in an autocrine manner through connexin43 hemichannel mediated ATP release. Biochim. Biophys. Acta Gen. Subj. 2018, 1862, 385-393. [CrossRef]

87. Maatouk, L.; Yi, C.; Carrillo-de Sauvage, M.A.; Compagnion, A.C.; Hunot, S.; Ezan, P.; Hirsch, E.C.; Koulakoff, A.; Pfrieger, F.W.; Tronche, F.; et al. Glucocorticoid receptor in astrocytes regulates midbrain dopamine neurodegeneration through connexin hemichannel activity. Cell Death Differ. 2019, 26, 580-596. [CrossRef]

88. Cea, L.A.; Cisterna, B.A.; Puebla, C.; Frank, M.; Figueroa, X.F.; Cardozo, C.; Willecke, K.; Latorre, R.; Saez, J.C. De novo expression of connexin hemichannels in denervated fast skeletal muscles leads to atrophy. Proc. Natl. Acad. Sci. USA 2013, 110, 16229-16234. [CrossRef]

89. Zhou, K.Q.; Green, C.R.; Bennet, L.; Gunn, A.J.; Davidson, J.O. The role of connexin and pannexin channels in perinatal brain injury and inflammation. Front. Physiol. 2019, 10, 141. [CrossRef]

90. Galinsky, R.; Davidson, J.O.; Dean, J.M.; Green, C.R.; Bennet, L.; Gunn, A.J. Glia and hemichannels: Key mediators of perinatal encephalopathy. Neural Regen. Res. 2018, 13, 181-189.

91. Froger, N.; Orellana, J.A.; Calvo, C.F.; Amigou, E.; Kozoriz, M.G.; Naus, C.C.; Saez, J.C.; Giaume, C. Inhibition of cytokine-induced connexin 43 hemichannel activity in astrocytes is neuroprotective. Mol. Cell. Neurosci. 2010, 45, 37-46. [CrossRef] [PubMed]

92. Buser, J.R.; Maire, J.; Riddle, A.; Gong, X.; Nguyen, T.; Nelson, K.; Luo, N.L.; Ren, J.; Struve, J.; Sherman, L.S.; et al. Arrested preoligodendrocyte maturation contributes to myelination failure in premature infants. Ann. Neurol. 2012, 71, 93-109. [CrossRef] [PubMed]

93. Yoon, B.H.; Romero, R.; Kim, C.J.; Koo, J.N.; Choe, G.; Syn, H.C.; Chi, J.G. High expression of tumor necrosis factor-alpha and interleukin-6 in periventricular leukomalacia. Am. J. Obstet. Gynecol. 1997, 177, 406-411. [CrossRef]

94. Mallard, C.; Davidson, J.O.; Tan, S.; Green, C.R.; Bennet, L.; Robertson, N.J.; Gunn, A.J. Astrocytes and microglia in acute cerebral injury underlying cerebral palsy associated with preterm birth. Pediatr. Res. 2014, 75, 234-240. [CrossRef] [PubMed]

95. Fleiss, B.; Gressens, P. Tertiary mechanisms of brain damage: A new hope for treatment of cerebral palsy? Lancet Neurol. 2012, 11, 556-566. [CrossRef]

96. Pekny, M.; Pekna, M. Reactive gliosis in the pathogenesis of CNS diseases. Biochim. Biophys. Acta 2016, 1862, 483-491. [CrossRef] [PubMed]

97. Volpe, J.J. Dysmaturation of premature brain: Importance, cellular mechanisms, and potential interventions. Pediatr. Neurol. 2019, 95, 42-66. [CrossRef] [PubMed]

98. Back, S.A. White matter injury in the preterm infant: Pathology and mechanisms. Acta Neuropathol. 2017, 134, 331-349. [CrossRef]

99. Xing, L.; Yang, T.; Cui, S.; Chen, G. Connexin hemichannels in astrocytes: Role in CNS disorders. Front. Mol. Neurosci. 2019, 12, 23. [CrossRef]

100. Rash, J.E.; Yasumura, T.; Dudek, F.E.; Nagy, J.I. Cell-specific expression of connexins and evidence of restricted gap junctional coupling between glial cells and between neurons. J. Neurosci. 2001, 21, 1983-2000. [CrossRef]

101. John, S.A.; Kondo, R.; Wang, S.Y.; Goldhaber, J.I.; Weiss, J.N. Connexin-43 hemichannels opened by metabolic inhibition. J. Biol. Chem. 1999, 274, 236-240. [CrossRef] [PubMed]

102. Rodriguez-Sinovas, A.; Cabestrero, A.; Lopez, D.; Torre, I.; Morente, M.; Abellan, A.; Miro, E.; Ruiz-Meana, M.; Garcia-Dorado, D. The modulatory effects of connexin 43 on cell death/survival beyond cell coupling. Prog. Biophys. Mol. Biol. 2007, 94, 219-232. [CrossRef] [PubMed]

103. Quist, A.P.; Rhee, S.K.; Lin, H.; Lal, R. Physiological role of gap-junctional hemichannels. Extracellular calcium-dependent isosmotic volume regulation. J. Cell Biol. 2000, 148, 1063-1074. [CrossRef] [PubMed]

104. Orellana, J.A.; Hernandez, D.E.; Ezan, P.; Velarde, V.; Bennett, M.V.; Giaume, C.; Saez, J.C. Hypoxia in high glucose followed by reoxygenation in normal glucose reduces the viability of cortical astrocytes through increased permeability of connexin 43 hemichannels. Glia 2010, 58, 329-343. [CrossRef] [PubMed] 
105. Davidson, J.O; Drury, P.P.; Green, C.R.; Nicholson, L.F.; Bennet, L.; Gunn, A.J. Connexin hemichannel blockade is neuroprotective after asphyxia in preterm fetal sheep. PLoS ONE 2014, 9, e96558. [CrossRef] [PubMed]

106. Davidson, J.O.; Green, C.R.; Nicholson, L.F.; Bennet, L.; Gunn, A.J. Connexin hemichannel blockade is neuroprotective after, but not during, global cerebral ischemia in near-term fetal sheep. Exp. Neurol. 2013, 248, 301-308. [CrossRef] [PubMed]

107. Davidson, J.O.; Rout, A.L.; Wassink, G.; Yuill, C.A.; Zhang, F.G.; Green, C.R.; Bennet, L.; Gunn, A.J. Non-additive effects of delayed connexin hemichannel blockade and hypothermia after cerebral ischemia in near-term fetal sheep. J. Cereb. Blood Flow Metab. 2015, 35, 2052-2061. [CrossRef]

108. Song, I.; Dityatev, A. Crosstalk between glia, extracellular matrix and neurons. Brain Res. Bull. 2018, 136, 101-108. [CrossRef] [PubMed]

109. Wiese, S.; Karus, M.; Faissner, A. Astrocytes as a source for extracellular matrix molecules and cytokines. Front. Pharmacol. 2012, 3, 120. [CrossRef]

110. Jones, E.V.; Bouvier, D.S. Astrocyte-secreted matricellular proteins in CNS remodelling during development and disease. Neural. Plast. 2014, 2014, 321209. [CrossRef]

111. Ferrer-Ferrer, M.; Dityatev, A. Shaping synapses by the neural extracellular matrix. Front. Neuroanat. 2018, 12, 40. [CrossRef] [PubMed]

112. Ralay Ranaivo, H.; Hodge, J.N.; Choi, N.; Wainwright, M.S. Albumin induces upregulation of matrix metalloproteinase-9 in astrocytes via MAPK and reactive oxygen species-dependent pathways. J. Neuroinflamm. 2012, 9, 68. [CrossRef] [PubMed]

113. Rosenberg, G.A.; Cunningham, L.A.; Wallace, J.; Alexander, S.; Estrada, E.Y.; Grossetete, M.; Razhagi, A.; Miller, K.; Gearing, A. Immunohistochemistry of matrix metalloproteinases in reperfusion injury to rat brain: Activation of MMP-9 linked to stromelysin-1 and microglia in cell cultures. Brain Res. 2001, 893, 104-112. [CrossRef]

114. Krishnaswamy, V.R.; Benbenishty, A.; Blinder, P.; Sagi, I. Demystifying the extracellular matrix and its proteolytic remodeling in the brain: Structural and functional insights. Cell. Mol. Life Sci. 2019, 76, 3229-3248. [CrossRef] [PubMed]

115. Kinoshita, M.; Nasu-Tada, K.; Fujishita, K.; Sato, K.; Koizumi, S. Secretion of matrix metalloproteinase-9 from astrocytes by inhibition of tonic P2Y14-receptor-mediated signal(s). Cell. Mol. Neurobiol. 2013, 33, 47-58. [CrossRef] [PubMed]

116. Hagen, M.W.; Riddle, A.; McClendon, E.; Gong, X.; Shaver, D.; Srivastava, T.; Dean, J.M.; Bai, J.Z.; Fowke, T.M.; Gunn, A.J.; et al. Role of recurrent hypoxia-ischemia in preterm white matter injury severity. PLoS ONE 2014, 9, e112800. [CrossRef] [PubMed]

117. Happel, M.F.K.; Frischknecht, R. Neuronal plasticity in the juvenile and adult brain regulated by the extracellular matrix. In Composition and Function of the Extracellular Matrix in the Human Body; IntechOpen: Rijeka, Croatia, 2016.

118. Wen, T.H.; Afroz, S.; Reinhard, S.M.; Palacios, A.R.; Tapia, K.; Binder, D.K.; Razak, K.A.; Ethell, I.M. Genetic reduction of matrix metalloproteinase-9 promotes formation of perineuronal nets around parvalbumin-expressing interneurons and normalizes auditory cortex responses in developing fmr1 knock-out mice. Cereb. Cortex 2018, 28, 3951-3964. [CrossRef]

119. Lemarchant, S.; Pruvost, M.; Montaner, J.; Emery, E.; Vivien, D.; Kanninen, K.; Koistinaho, J. ADAMTS proteoglycanases in the physiological and pathological central nervous system. J. Neuroinflamm. 2013, 10, 133. [CrossRef]

120. Leonardo, C.C.; Eakin, A.K.; Ajmo, J.M.; Collier, L.A.; Pennypacker, K.R.; Strongin, A.Y.; Gottschall, P.E. Delayed administration of a matrix metalloproteinase inhibitor limits progressive brain injury after hypoxia-ischemia in the neonatal rat. J. Neuroinflamm. 2008, 5, 34. [CrossRef]

121. Bednarek, N.; Svedin, P.; Garnotel, R.; Favrais, G.; Loron, G.; Schwendiman, L.; Hagberg, H.; Morville, P.; Mallard, C.; Gressens, P. Increased MMP-9 and TIMP-1 in mouse neonatal brain and plasma and in human neonatal plasma after hypoxia-ischemia: A potential marker of neonatal encephalopathy. Pediatr. Res. 2012, 71, 63-70. [CrossRef]

122. Planas, A.M.; Sole, S.; Justicia, C. Expression and activation of matrix metalloproteinase-2 and -9 in rat brain after transient focal cerebral ischemia. Neurobiol. Dis. 2001, 8, 834-846. [CrossRef] [PubMed] 
123. Amantea, D.; Russo, R.; Gliozzi, M.; Fratto, V.; Berliocchi, L.; Bagetta, G.; Bernardi, G.; Corasaniti, M.T. Early upregulation of matrix metalloproteinases following reperfusion triggers neuroinflammatory mediators in brain ischemia in rat. Int. Rev. Neurobiol. 2007, 82, 149-169. [PubMed]

124. Cross, A.K.; Haddock, G.; Stock, C.J.; Allan, S.; Surr, J.; Bunning, R.A.; Buttle, D.J.; Woodroofe, M.N. ADAMTS- 1 and -4 are up-regulated following transient middle cerebral artery occlusion in the rat and their expression is modulated by TNF in cultured astrocytes. Brain Res. 2006, 1088, 19-30. [CrossRef] [PubMed]

125. Al Qteishat, A.; Gaffney, J.J.; Krupinski, J.; Slevin, M. Hyaluronan expression following middle cerebral artery occlusion in the rat. NeuroReport 2006, 17, 1111-1114. [CrossRef] [PubMed]

126. Romanic, A.M.; White, R.F.; Arleth, A.J.; Ohlstein, E.H.; Barone, F.C. Matrix metalloproteinase expression increases after cerebral focal ischemia in rats: Inhibition of matrix metalloproteinase-9 reduces infarct size. Stroke 1998, 29, 1020-1030. [CrossRef]

127. Sunagawa, S.; Ichiyama, T.; Honda, R.; Fukunaga, S.; Maeba, S.; Furukawa, S. Matrix metalloproteinase-9 and tissue inhibitor of metalloproteinase-1 in perinatal asphyxia. Brain Dev. 2009, 31, 588-593. [CrossRef]

128. Al'Qteishat, A.; Gaffney, J.; Krupinski, J.; Rubio, F.; West, D.; Kumar, S.; Kumar, P.; Mitsios, N.; Slevin, M. Changes in hyaluronan production and metabolism following ischaemic stroke in man. Brain 2006, 129 Pt 8 , 2158-2176. [CrossRef]

129. Gu, Z.; Cui, J.; Brown, S.; Fridman, R.; Mobashery, S.; Strongin, A.Y.; Lipton, S.A. A highly specific inhibitor of matrix metalloproteinase-9 rescues laminin from proteolysis and neurons from apoptosis in transient focal cerebral ischemia. J. Neurosci. 2005, 25, 6401-6408. [CrossRef]

130. Cocozzelli, A.G.; White, T.W. Connexin 43 mutations lead to increased hemichannel functionality in skin disease. Int. J. Mol. Sci. 2019, 20, 6168. [CrossRef]

131. Deva, N.C.; Zhang, J.; Green, C.R.; Danesh-Meyer, H.V. Connexin43 modulation inhibits scarring in a rabbit eye glaucoma trabeculectomy model. Inflammation 2012, 35, 1276-1286. [CrossRef]

132. O'Carroll, S.J.; Gorrie, C.A.; Velamoor, S.; Green, C.R.; Nicholson, L.F. Connexin 43 mimetic peptide is neuroprotective and improves function following spinal cord injury. Neurosci. Res. 2013, 75, $256-267$. [CrossRef] [PubMed]

133. Gangoso, E.; Talaveron, R.; Jaraiz-Rodriguez, M.; Dominguez-Prieto, M.; Ezan, P.; Koulakoff, A.; Medina, J.M.; Giaume, C.; Tabernero, A. A c-Src inhibitor peptide based on connexin43 exerts neuroprotective effects through the inhibition of glial hemichannel activity. Front. Mol. Neurosci. 2017, 10, 418. [CrossRef] [PubMed]

134. Tonkin, R.S.; Bowles, C.; Perera, C.J.; Keating, B.A.; Makker, P.G.S.; Duffy, S.S.; Lees, J.G.; Tran, C.; Don, A.S.; Fath, T.; et al. Attenuation of mechanical pain hypersensitivity by treatment with Peptide5, a connexin-43 mimetic peptide, involves inhibition of NLRP3 inflammasome in nerve-injured mice. Exp. Neurol. 2018, 300, 1-12. [CrossRef]

135. Chen, M.J.; Kress, B.; Han, X.; Moll, K.; Peng, W.; Ji, R.R.; Nedergaard, M. Astrocytic CX43 hemichannels and gap junctions play a crucial role in development of chronic neuropathic pain following spinal cord injury. Glia 2012, 60, 1660-1670. [CrossRef] [PubMed]

136. Schock, S.C.; Leblanc, D.; Hakim, A.M.; Thompson, C.S. ATP release by way of connexin 36 hemichannels mediates ischemic tolerance in vitro. Biochem. Biophys. Res. Commun. 2008, 368, 138-144. [CrossRef]

137. Thompson, R.J.; Jackson, M.F.; Olah, M.E.; Rungta, R.L.; Hines, D.J.; Beazely, M.A.; MacDonald, J.F.; MacVicar, B.A. Activation of pannexin-1 hemichannels augments aberrant bursting in the hippocampus. Science 2008, 322, 1555-1559. [CrossRef]

138. Weilinger, N.L.; Tang, P.L.; Thompson, R.J. Anoxia-induced NMDA receptor activation opens pannexin channels via Src family kinases. J. Neurosci. 2012, 32, 12579-12588. [CrossRef]

139. Freitas-Andrade, M.; Bechberger, J.F.; MacVicar, B.A.; Viau, V.; Naus, C.C. Pannexin1 knockout and blockade reduces ischemic stroke injury in female, but not in male mice. Oncotarget 2017, 8, 36973-36983. [CrossRef]

140. Cisneros-Mejorado, A.; Gottlieb, M.; Cavaliere, F.; Magnus, T.; Koch-Nolte, F.; Scemes, E.; Perez-Samartin, A.; Matute, C. Blockade of P2X7 receptors or pannexin-1 channels similarly attenuates postischemic damage. J. Cereb. Blood Flow Metab. 2015, 35, 843-850. [CrossRef]

141. Kim, Y.; Griffin, J.M.; Harris, P.W.; Chan, S.H.; Nicholson, L.F.; Brimble, M.A.; O'Carroll, S.J.; Green, C.R. Characterizing the mode of action of extracellular connexin 43 channel blocking mimetic peptides in an in vitro ischemia injury model. Biochim. Biophys. Acta Gen. Subj. 2017, 1861, 68-78. [CrossRef]

142. Mazur, M.; Miller, R.H.; Robinson, S. Postnatal erythropoietin treatment mitigates neural cell loss after systemic prenatal hypoxic-ischemic injury. J. Neurosurg. Pediatr. 2010, 6, 206-221. [CrossRef] [PubMed] 
143. George, S.; Scotter, J.; Dean, J.M.; Bennet, L.; Waldvogel, H.J.; Guan, J.; Faull, R.L.; Gunn, A.J. Induced cerebral hypothermia reduces post-hypoxic loss of phenotypic striatal neurons in preterm fetal sheep. Exp. Neurol. 2007, 203, 137-147. [CrossRef] [PubMed]

144. Kilkenny, C.; Browne, W.J.; Cuthill, I.C.; Emerson, M.; Altman, D.G. Improving bioscience research reporting: The ARRIVE guidelines for reporting animal research. Osteoarthr. Cartil. 2012, 20, 256-260. [CrossRef] [PubMed]

145. Gunn, A.J.; Gunn, T.R.; de Haan, H.H.; Williams, C.E.; Gluckman, P.D. Dramatic neuronal rescue with prolonged selective head cooling after ischemia in fetal lambs. J. Clin. Investig. 1997, 99, 248-256. [CrossRef] [PubMed]

146. Williams, C.E.; Gunn, A.J.; Mallard, C.; Gluckman, P.D. Outcome after ischemia in the developing sheep brain: An electroencephalographic and histological study. Ann. Neurol. 1992, 31, 14-21. [CrossRef] [PubMed]

147. Gluckman, P.D.; Parsons, Y. Stereotaxic method and atlas for the ovine fetal forebrain. J. Dev. Physiol. 1983, 5, 101-128.

148. Hartig, W.; Brauer, K.; Bruckner, G. Wisteria floribunda agglutinin-labelled nets surround parvalbumin-containing neurons. NeuroReport 1992, 3, 869-872. [CrossRef]

149. Koppe, G.; Bruckner, G.; Brauer, K.; Hartig, W.; Bigl, V. Developmental patterns of proteoglycan-containing extracellular matrix in perineuronal nets and neuropil of the postnatal rat brain. Cell Tissue Res. 1997, 288, 33-41. [CrossRef]

150. Scher, M.S.; Aso, K.; Beggarly, M.E.; Hamid, M.Y.; Steppe, D.A.; Painter, M.J. Electrographic seizures in preterm and full-term neonates: Clinical correlates, associated brain lesions, and risk for neurologic sequelae. Pediatrics 1993, 91, 128-134.

151. Galinsky, R.; Davidson, J.O.; Bennet, L.; Green, C.R.; Gunn, A.J. Connexin hemichannel blockade improves survival of striatal neurons after perinatal cerebral ischaemia. J. Paediatr. Child Health 2015, 51, 60.

(C) 2020 by the authors. Licensee MDPI, Basel, Switzerland. This article is an open access article distributed under the terms and conditions of the Creative Commons Attribution (CC BY) license (http://creativecommons.org/licenses/by/4.0/). 